\title{
Reference Waste Forms and Packing Material for the Nevada Nuclear Waste Storage Investigations Project
}

\author{
V. M. Oversby
}

Manuscript date: March 30, 1984

DISCLAIMER

This report was prepared as an account of kork sponsored by an agency of the United States Government. Neither the United Stale:; Government nor any ages -y thereof, nor any of their employces, makes any warranty, express or implied, or assumes any legal liability or responsibility for the accuracy. completeness, or usefulness of any information, apparatus, product, or process disclosed, or represents that its use would not infringe privately owned rights. Reference herein to any specific commercial product, process, or service by trade name, trademark, manufacturer, or otherwise docs not necersarily conslitute or imply its endorsement, recommenuation, or favoring by the United States Government if any agency thereof. The views and opinions of authors expressed berein do not necessarily state or rellect those of the United States Goveinment or any agency thereof.

\section{LAWRENCE LIVERMORE NATIONAL LABORATORY University of California - Livermore, California • 94550}




\section{Contents}

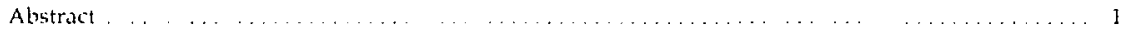

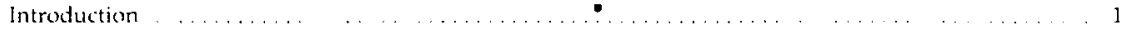

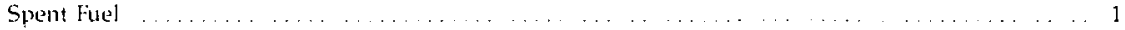

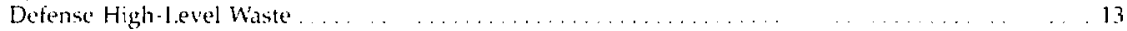

Commercial High-level Waste: West Valley . . . . . . . . . . . . . . . . . . . . . 18

Commerial High-Lerel Waste: Potential Waste forms . . . . . . . . $\ldots \ldots \ldots \ldots$

racking Material . . . . . . . . . . . . . . . . 23

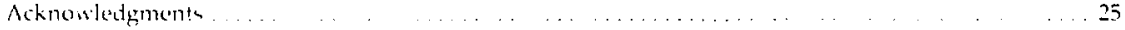

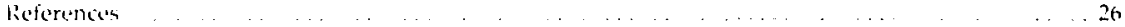




\title{
Reference Waste Forms and Packing Material for the Nevada Nuclear Waste Storage Investigations Project
}

\begin{abstract}
The Lawrence Livermore National Laboratory (LLNL), Livermore, Calif, has been given the tash of designing and verifying the performanee of waste packages for the 1 "vacta Nuclear Waste Storage Investigations (NNW'SI) Project. NNWSI is studying the" sutability of the tuffaceous rocks at Yucca Mountain. Nevada Test Site for the potential construction of a high-level nuclear waste repository. This report gives a summary description of the three waste forms for which LLNL is designing waste packages: spent fued, either as intact asienblies or as consolidated fuel pins, reprocessed commercial high-level waste in the form of borosilicate glass, and reprocessed defense high-level waste from the Defense Waste Processing Facility in Aiken, S.C. Reference packing material for use with the alternative wasts package design for spent fuel is also described.
\end{abstract}

\section{Introduction}

The Nevada Vuclear Waste Stora:re Investifrations (NNW'SI) Project is studving the suitability of the tuffacenum rocks at Yueca Mountain, Nevada Test Site, for : lie potential construction of a high-level nuclear waste repository. Lawrence Livermore National l.aboratory (LLNL), Livermore. Calif., has been given the task of designing and verifying the performance of waste packages for the NNIVSI Project.

The waste forms for which waste packages are being designed are spent fuel, either as intact assemblies or as consolidated fuel pins, reprocessed commercial high-level waste in the form of borosilicate glass. and reprocessed defense high. level waste from the Defense Waste Processing Facility (DWPF), Aiken, S. C. The purpose of this document is to provide a summary description of these three waste forms. The horesilicate glase that will be produced at tiest balles: $N$... and the reference packing material that is under consideration for use with spent fuel wiante packages are also destribed.

The reference spent fuel for NNISSI waste form testing is pressurized water resctor (PWR) fuel of moderate burnup and low fission gas re. lease from the Turkev roint and $H$. B. Robinson reactors. The reference wast form for Delente High-Lerel Waste is burosilicate ghass based on Frit 165. The Commercial High-tered Minte tenting materials are based on a borosilicate glass formulation PNI. 76-68. The reference paching material is Topopah Spring turt Yuces Muuntain, Nev., crust ad to pass through 100-nwesh screen and compressed isostatically at 20,000$)$ psi.

\section{Spent Fuel}

Spent fuel, for the purposes of this report, is fuel macerial contained in cladding that has been irractiated in a light water commercial power reactor (LWR). All fuel that was discharged from LW reactors prior to 1969 was reprocessed. Table 1 gives the accumulated sperit fuel population at the end of 1982 as a function of discharge wate and burnup. The total accumulation at the end of 1982 
Table 1. Burnup and time of discharge of commercial spent fuel in inventory."

\begin{tabular}{|c|c|c|c|c|c|c|c|c|c|c|c|c|c|c|c|c|}
\hline \multirow[b]{3}{*}{ Year } & \multicolumn{16}{|c|}{ Burnup (MWd/MTIHM) } \\
\hline & \multicolumn{2}{|c|}{$0-5,000$} & \multicolumn{2}{|c|}{$5,000-10,000$} & \multicolumn{2}{|c|}{$10,000-15,000$} & \multicolumn{2}{|c|}{$15,000-20,000$} & \multicolumn{2}{|c|}{$20,000-25,000$} & \multicolumn{2}{|c|}{$25,000-30,000$} & \multicolumn{2}{|c|}{$30,000-35,000$} & \multicolumn{2}{|c|}{$35,000-40,000$} \\
\hline & $\overline{\mathbf{B W R}}$ & $\overline{P W R}$ & $\overline{\text { BWR }}$ & PWR & $\overline{B W R}$ & PWR & $\overline{\mathrm{BWR}}$ & $\overline{\mathrm{PWR}}$ & $\overline{B W R}$ & PWIR & $\overline{B W R}$ & $\overline{\text { PWR }}$ & $\overline{\mathrm{BWR}}$ & $\overline{\text { PWR }}$ & $\overline{B W R}$ & PWR \\
\hline 1969 & & & 0.2 & & 0.9 & & 7.1 & & 0.2 & & & 7.8 & & & & \\
\hline 1970 & & & & & & & & 40.5 & & 7.8 & & & & & & \\
\hline 1971 & & & 13.9 & & 5.5 & 4.6 & & & & & & 40.0 & & & & \\
\hline 1972 & 141.6 & & 11.8 & & $3 \mathrm{t} .4$ & 7.8 & 4.0 & 45.0 & & & & 9.2 & & 21.7 & & \\
\hline 1973 & 9.1 & & 16.3 & & 35.6 & & +0.1 & 24.2 & & & & 39.7 & & & & \\
\hline 1974 & 59.9 & & 6.2 & 7.1 & 121.5 & 77.0 & 31.0 & 39.6 & 3.8 & 13.9 & & 74.0 & & & & \\
\hline 1975 & & & 0.7 & 9.3 & 4.5 .7 & 186.3 & 155.2 & 11.9 & 21.9 & 70.8 & & 41.2 & & 19.8 & & \\
\hline 1976 & 0.1 & & 49.4 & & 108.0 & 16.5 & 149.3 & 147.0 & & 83.8 & & 91.3 & & 37.2 & & \\
\hline 1977 & & & 52. I & & 34.2 & & 174.2 & 131.8 & 102.2 & 126.4 & & 134.1 & & 85.9 & & 18.4 \\
\hline 1978 & & & & 1.8 & 24.5 & 51.1 & 118.8 & 78.3 & 266.4 & 45.3 & 28.4 & 401.5 & & 72.5 & & 62.1 \\
\hline 1979 & & & & & 19.6 & 26.0 & 91.6 & 123.8 & 161.3 & 55.3 & 178.2 & 278.5 & & 238.9 & & 31.6 \\
\hline 1980 & 15.4 & & & & 2.7 & 9.0 & 45.7 & & 352.4 & 55.3 & 110.0 & 303.7 & & 226.0 & & 28.8 \\
\hline 1981 & & & & & & 25.5 & 73.2 & & 255.9 & & 161.0 & 303.9 & & 428.1 & & 16.0 \\
\hline 1982 & & & & & 14.5 & & . & 79.5 & 30.0 & 88.7 & 300.0 & 161.4 & & 360.6 & & 15.2 \\
\hline
\end{tabular}

From DOE/NE-0017/2 (1983).

" MTIHM :- metric tons initial heavy metal. 
was $3732.5 \mathrm{MTIHM}$ (metric tons initial hear: metal) of boiling water reactor (BWR) spent fuel and $5256.1 \mathrm{MTIHM}$ of PIVR spent fuel.

Figure 1 shows a typical fuel pin design used in a PIV and Fig. 2 is a typical PW'R assembly:
Figure 3 represents a fuel pin and assembly geometry for a typical BWR. Assembly sis's, fuel pin dimensions. and datding type vary with reactor design. Table 2 lists typical characteristics: for more detailed discussions consult Woodley (1983).

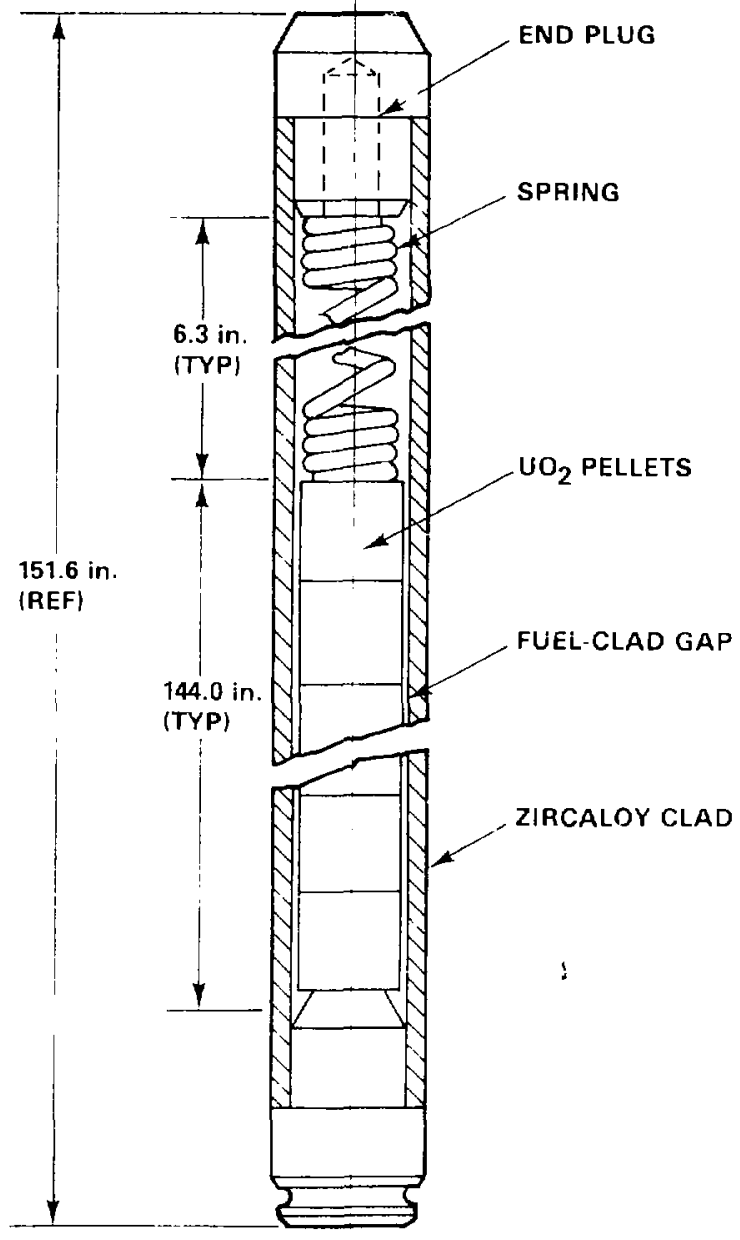

Figure 1. Westinghouse PWR fuel rod. Specific dimensions depend on design variables, such as prepressurization, power history, and discharge burnup (Woodley, 1983). Figure provided by Hanford Engineering Development Laboratory (HEDL), Richland, Wash., Report HEDL-TME 83-28. 


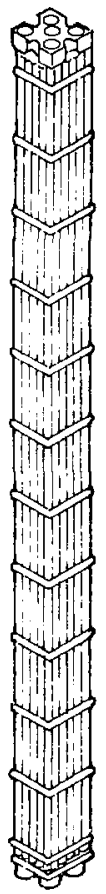

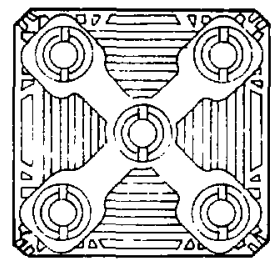

TOP VIEW

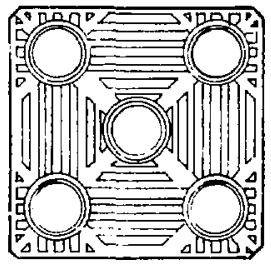

BOTTOM VIEW

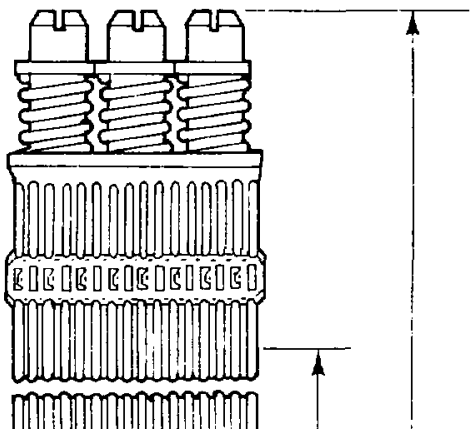

176.8 in.

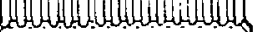

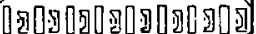

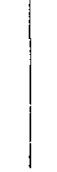

150 in.

ACTIVE

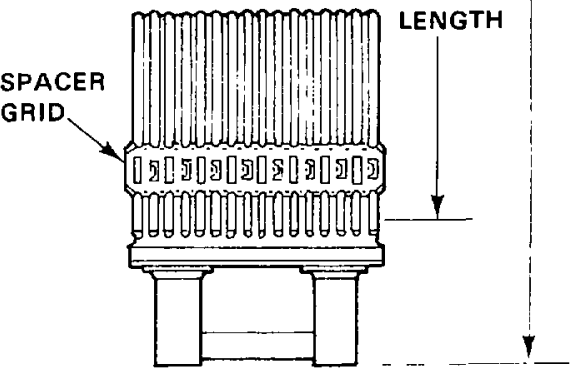

Figure 2. Combustion Engineering, Inc. PWR fuel assembly (Woodley, 1983). Figure proviced by Hanford Engineering Development Laborstory (HEDL), Richland, Wash., Report HEDL-TME 83-28.

Most LWR fuel pins consist of a stack of UO pellets enclosed in Zircaloy cladding. Three PWRs and onc BWR use fuel pins with stainless steel (SS) clatding. Spent iliel from these reactors represents about $3 \%$ of the total inventory. The initial internal atmosphere of the fuel pins is helium at 1 atm (up) to 1977) or $3 \mathrm{~atm}$ (1977 on) pressure in BWR pins and 1 to $30 \mathrm{~atm}$ pressure in PWR pins (Woodley, 1983).
Loss of cladifing integrity occurs for a small percentage of fuel pins during irradiation. Figure 4 show's estimates of the failure rate for PWR and BWR pins as a function of tine (Carzarolli et al., 1979). The failure rate for current and future fue] pins during in-reactor service seems likely to continue at approximately $0.01 \%$ of the pins (Woodley, 1983). Typical cladding defects are small cracks or pin holes. 


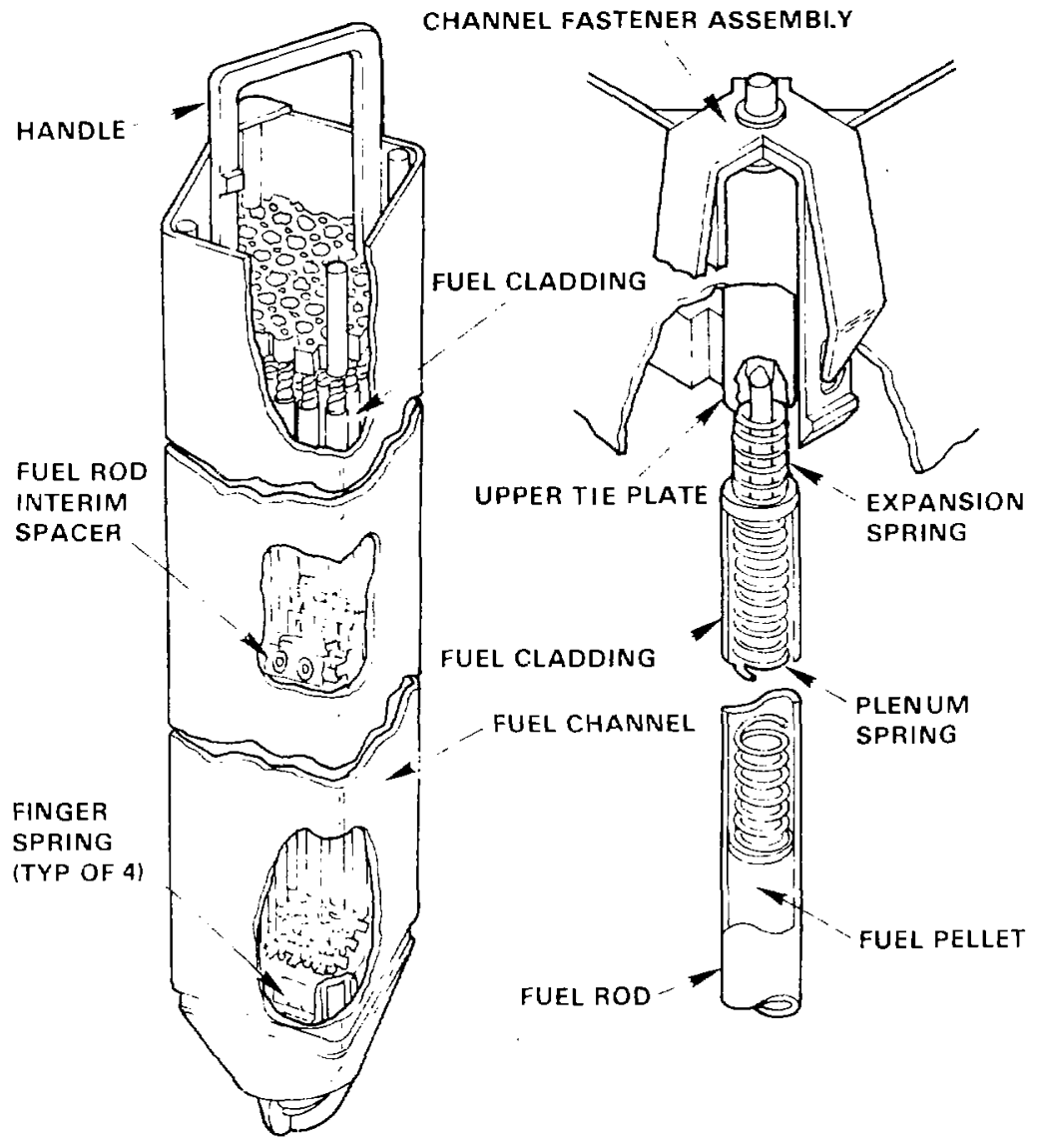

Figure 3. General Electric Company BWR fuel assembly, Woodiey, 1983l. Figure provided by Hanford Engineering Development Laboratory (11EDL), Richland, Wash., Report 11LDLTME 83-28.

During irradiation some of the original uranium in the fucl is transformed inte fission prod. uct or higher actinides. The exact ineentory of these nuclides at the end of irradiation depends on the reactor operaling tharacteristics and the duration of irradiation. Estimater of the isotepic and chemical composition of spent fuel haw been made with the GRIGEN2 code (DOE: NE-DOJ $/ 2$, 1983). These estimates were preserted for the total inventory accumulation of sperat fuel. 
Table 2. Physical characteristics of LWR fuel assemblies. ${ }^{a, b}$

\begin{tabular}{|c|c|c|}
\hline Characteristics & BWR & PWR \\
\hline Overall assembly length & $4.470 \mathrm{~m}$ & $4.059 \mathrm{~m}$ \\
\hline Cross section & $13.9 \times 13.9 \mathrm{~cm}$ & $21.4 \times 21.4 \mathrm{~cm}$ \\
\hline Fuel element length & $4.064 \mathrm{~m}$ & $3.851 \mathrm{~m}$ \\
\hline Active fuel height & $3.759 \mathrm{~m}$ & $3.658 \mathrm{~m}$ \\
\hline Fuel element (outer diameter) & $1.252 \mathrm{~cm}$ & $0.950 \mathrm{~cm}$ \\
\hline Fuel element array & $B \times 8$ & $17 \times 17$ \\
\hline Fuel elements/assembly & 63 & 264 \\
\hline Assembly total weight & $319.9 \mathrm{~kg}$ & $657.9 \mathrm{kB}$ \\
\hline Uranium/assembly & $183.3 \mathrm{~kg}$ & $461.4 \mathrm{~kg}$ \\
\hline $\mathrm{LO}_{2} /$ assembly & $208.0 \mathrm{~kg}$ & $523.4 \mathrm{~kg}$ \\
\hline Zircaloy/assembly & $99.5 \mathrm{~kg}^{\prime}$ & $108.4^{4}$ \\
\hline Lardivare/assembly & $12.4 \mathrm{~kg}^{\mathrm{r}}$ & $26.1 \mathrm{~kg}^{1}$ \\
\hline Total metal/assembly & $111.9 \mathrm{~kg}$ & $134.5 \mathrm{~kg}$ \\
\hline Nominal volume/assembly & $0.0864 \mathrm{~m}^{2^{4}}$ & $0.186 \mathrm{~m}^{34}$ \\
\hline \multicolumn{3}{|c|}{$\begin{array}{l}\text { "Irom DOE/NE-0017/2. } \\
\text { "Characteristics are based on } 1976-1977 \text { General Electric design data and } \\
475-1977 \text { Westinghouse design data. } \\
\text { "Includes Zircaloy fuel-element spacers and fuel channel. } \\
\text { "Includes Zircaloy control-rod guide thimbles. } \\
\text { "Includes SS tie-plates, Inconel springs, and plenum springs. } \\
\text { 'Includes SS nozzles and Inconel-718 grids. } \\
\text { "Rased on overall outside dimension. }\end{array}$} \\
\hline
\end{tabular}

Tabie 3 gives a selection of data from DOE/NE-0017/2 (1983) recalculated to a hasis of per MTIHM. The basis for selection of fission producis and activation products was half-life longer than 1 yr and a selection based on activity per MTIHM, which varied according to the halt lile. The fission products and activation products were divided into three groups:

$$
\begin{aligned}
& \text { Croup 1-Half-life between } 1 \text { and } 5 \text { yr: } \\
& \text { Croup Il-Half-life between } 5 \text { and } 31 \mathrm{yr} \text {; } \\
& \text { activity greater than } 0.3 \\
& \text { Ci/MTIHM } \\
& \text { Group III-Half-life over } 31 \text { yr; } \\
& \text { activity greater than } 0.01 \\
& \text { Ci/MTIHM }
\end{aligned}
$$

Talile 3 also includes three short-lived nuclides that are in secular equilibrium with longer lived parents and that contribute substantially to the total activity of the spent fuel.

Assuming 10-vr-old fuel as a reference case. nuclides with half-lives of less than 1 yr will have dreayed to less than $0.1 \%$ of their original (at dis(harge) activities and will constitute only a small proportion of the activity in the speni fuel Group I and Group It nuclides are the main con tributors to thermal power generalion and radiation field during the containment period, up to 300 to 1000 yr after disposal. At $300 \mathrm{yr}$ after disposal. Group 1 and II nuclides have decayed to less than $0.1 \%$ of their original activities. Decay heat generation and radivactivity in the post-300). yr period will be dominated by Group $11 \mathrm{ll}$ fission products and actinides. Table 4 gives the dominant actinides in spent fuel recalculated to a hasis of per MTIHM. It should be empliasized that the data in Tables 3 and 4 do not represent any individual spent fuel material bui are the average of the present inventory calculated by dividing total inventory estimates by total inventory weight of initial heavy metal.

Figure 5 plots the radioactivity and thermal power of PWR and BWR spent fuel as a function of burnup and decay time since discharge. The middle curve, for $25,000 \mathrm{MWd} / \mathrm{MTIHM}$ birnup, is the most representative of the current spent fuel imventory average.

The distribution of radionuclides within spent fuel is of interest when behavior of the fuel under geologic disposal conditions is considered. Some of the fission products and most of the actinides are present as oxides dissolved in the 

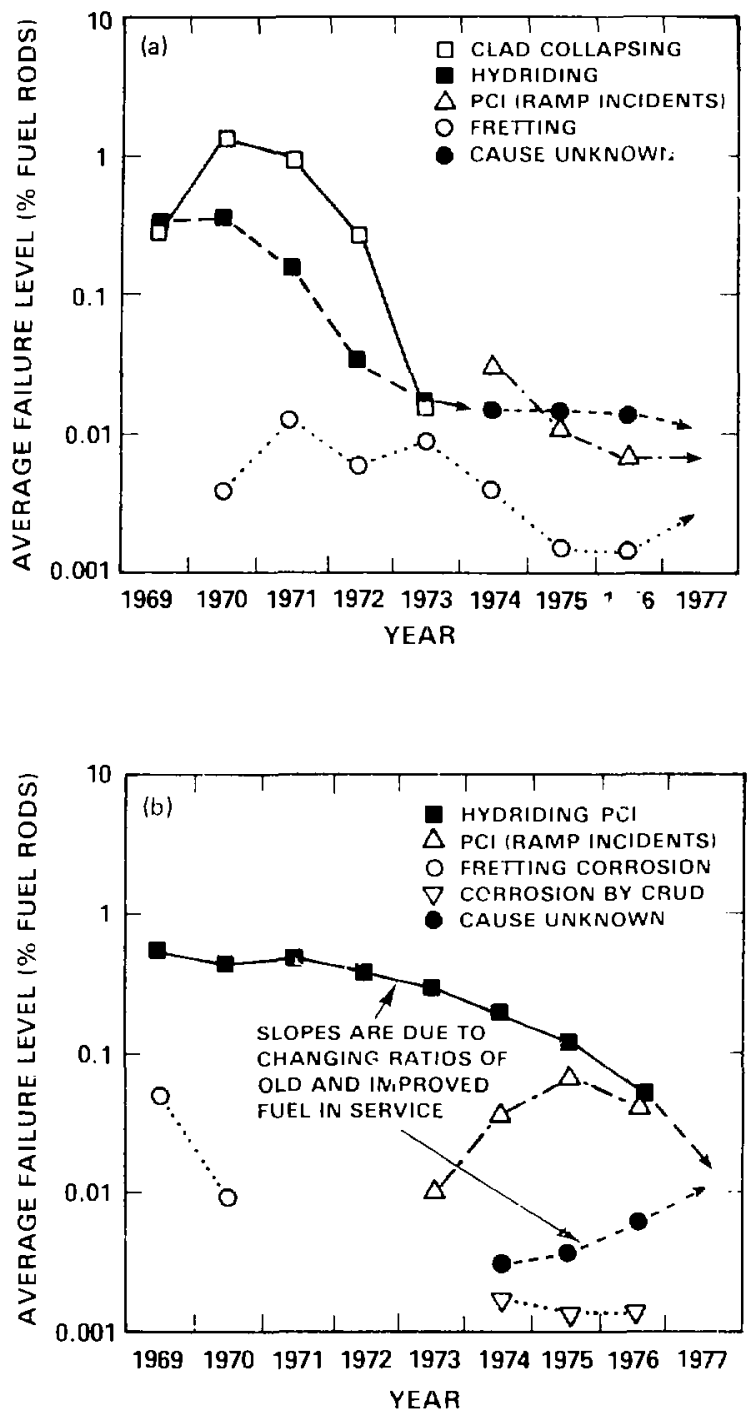

Figure 4. Estimates of the failure rate for (a) fuel rods in PWR plants and (b) fuel rods in BWR plants, (From Garzarolli et al., 1979.) 
Table 3. Inventory of dominant fission products and activiation products in spent fuel, cladding, and fuel assembly structural material with half-lives of 1 yr or longer."

\begin{tabular}{|c|c|c|c|}
\hline Isotope & Hall life $(y r)$ & g/MTIHM & Ci/MTIHM \\
\hline \multicolumn{4}{|l|}{ Group I } \\
\hline Fe-53 & 2.7 & 0.91 & $2.27 \times 10^{3}$ \\
\hline$R u \cdot 106$ & 1.01 & 27.4 & $9.17 \times 10^{4}$ \\
\hline [Rh-106] & $|29.8 \mathrm{~s}|$ & $2.6 \times 10=$ & $9.17 \times 10^{5}$ \\
\hline Sb-125 & 2.7 & 6.12 & $6.32 \times 10^{7}$ \\
\hline Cs-13i & 206 & 29.9 & $3.88 \times 10^{4}$ \\
\hline $19 m-147$ & 2.62 & 54 & $5.01 \times 10^{*}$ \\
\hline$F u-1.55$ & 4.4 & 6.0 & $2.74 \times 10^{4}$ \\
\hline \multicolumn{4}{|l|}{ Group 11} \\
\hline $11-3$ & 12.33 & 0.054 & 516 \\
\hline$(0)-60$ & 5.27 & 3.28 & $3.72 \times 10^{2}$ \\
\hline$K r-85$ & 10.7 & 13.6 & $5.32 \times 10^{1}$ \\
\hline $5 r-40$ & 28.6 & 346 & $4.73 \times 10^{2}$ \\
\hline$|r-40|$ & $|6+1 \mathrm{~h}|$ & 0.09 & $4.73 \times 10^{4}$ \\
\hline $\mathrm{Cd}-11.3 \mathrm{~m}$ & 14 & 0.15 & 33.3 \\
\hline$\{s-13\}$ & 30.17 & 780 & $6.79 \times 10^{4}$ \\
\hline$\left\{\mathrm{Ha}_{\mathrm{a}}-13 \mathrm{Zm}\right\}$ & {$[2.55 \mathrm{ml}]$} & $1.2 \times 10^{4}$ & $6.42 \times 10^{4}$ \\
\hline$t: u-1.52$ & 13.6 & 0.022 & 3.8 \\
\hline liu-154 & 8.3 & 18.9 & $5.09 \times 10^{3}$ \\
\hline \multicolumn{4}{|l|}{ Grotep 111} \\
\hline$C \cdot 14$ & 5730 & 0.33 & 1.47 \\
\hline $\mathrm{Ni}-54$ & $7.5 \times 10^{4}$ & +2.9 & 3.25 \\
\hline $\mathrm{Ni}-\mathrm{n} 3$ & 100 & 7.1 & +38 \\
\hline $5 \mathrm{~s}-74$ & $0.5 \times 10^{1}$ & 4.1 & 0.29 \\
\hline $2 r-93$ & $1.5 \times 10^{6}$ & 542 & $1 .+4$ \\
\hline Nh-94 & $2.0 \times 10^{1}$ & 4.37 & 0.82 \\
\hline Tc-49 & $2.14 \times 10^{2}$ & 5.56 & 4.41 \\
\hline$P d-11\} ?$ & $6.5 \times 10^{\prime \prime}$ & 156 & U. 08 \\
\hline$S n-12 t$ & 5.5 & $0.01 \bar{z}$ & 1.02 \\
\hline $5 n-12 h$ & $-1 \times 10^{5}$ & 19.5 & 0.55 \\
\hline $1 \times 124$ & $1.6 \times 10^{-}$ & 128 & 0.023 \\
\hline$C:-135$ & $3 \times 10^{4}$ & 218 & 0.75 \\
\hline $5 m-151$ & 90 & 11,0 & 288 \\
\hline
\end{tabular}

"Calculated from data io DOE/NE-no17/2 (1493); half-lives from Fritadlander el al. 119811 .

U(). Some fistion products form oxites that are insoluble in UO, or remain as metals: these malerials fend to form small-seale segregations in the LO , marrix. Some fission product. form nonoxido cumprounds either with the fuel or other fissionproduct elements, e.g. Csl. Finally, some tission products are present as inert gases.

During irradiation, particularly while temferature is changing rapidly, or at high fuel lemperatures $\left(\because-1000^{\circ} \mathrm{C}\right)$, gaseous fission products mas diffuse out of the $\mathrm{UO}_{2}$ matrix and collect in the gap hetween the pellets and the cladding. If the cladding subsequently fails, amy gas in the gap (a) easily escape. Figure 6 showi estimates of fission gas release from the pellet matrix to the pellet-cladding gap. Gas releace is much lower in the newer type pressurized fuel pins than in the older. unpressurized pins. Vulatile fission produste behave in a manner similar to the gaseous fission products if a high gas release occurs (Wuodley, 1983).

For fuel pins operated under cond tions that do not lead to high gas relnase, which includes must of the ans presently in use, fission products 
(a)
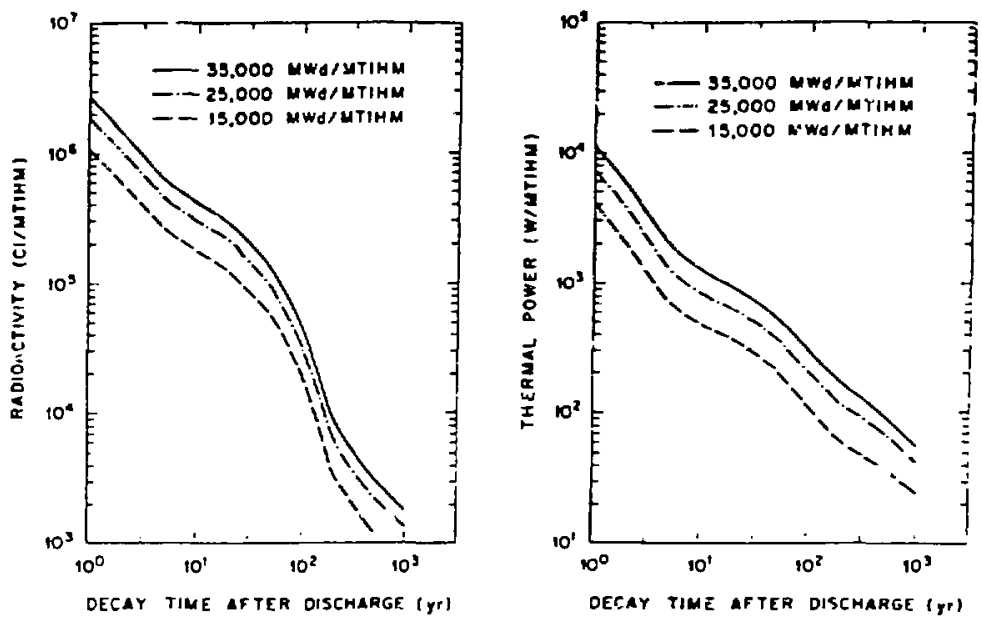

(b)
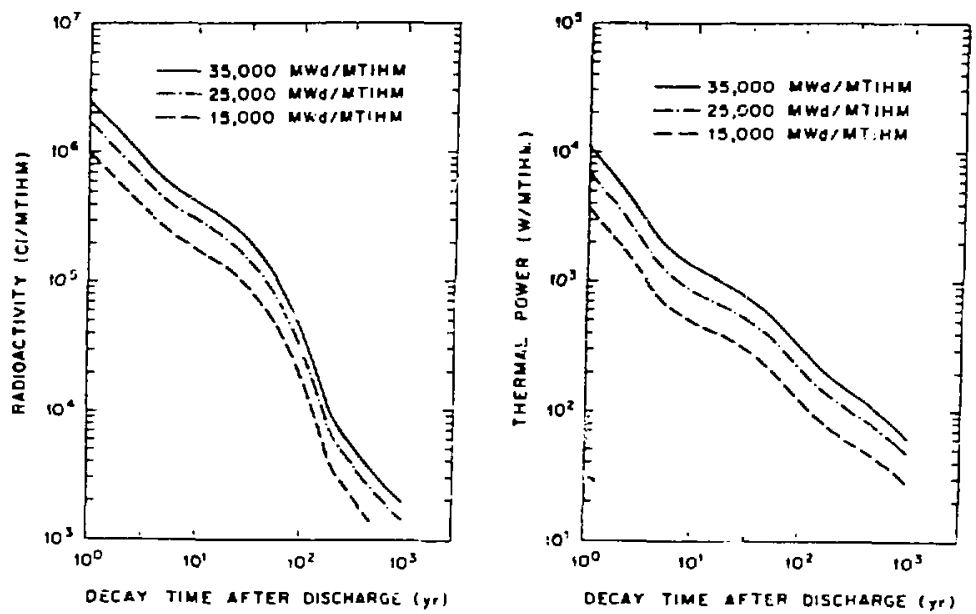

ligure 5. Radioactivity and thermal power of 1 metric ton of heavy mets! of (a) PWR and (b) BWR spent fuel as a function of burnup and time from reactor discharge. (From DOE/NE-0017,2, 1 83.) 
Table 4. Inventory average at the end of 1982 of dominant actinides in spent fuel. ${ }^{a}$

\begin{tabular}{|c|c|c|c|}
\hline Isotope & Half-life $(y r)$ & $\mathrm{g} / \mathrm{MTLHM}$ & Сі/МТЈНМ \\
\hline U-23i & $2.45 \times 10^{5}$ & 166 & 1.09 \\
\hline U-235 & $7.04 \times 10^{8}$ & $9.39 \times 10^{3}$ & 0.02 \\
\hline$U-236$ & $2.34 \times 10^{2}$ & $2.84 \times 10^{3}$ & 0.18 \\
\hline U.238 & $4.47 \times 10^{9}$ & $9.57 \times 10^{5}$ & 0.32 \\
\hline $\mathrm{No-237}$ & $2.14 \times 10^{6}$ & 276 & 0.20 \\
\hline$u-238$ & 87.74 & 77.6 & $1.34 \times 10^{3}$ \\
\hline Pu-239 & $2.41 \times 10^{4}$ & $4.76 \times 10^{3}$ & 296 \\
\hline $\mathrm{Pu}-240$ & $6.57 \times 10^{3}$ & $1.74 \times 10^{3}$ & 395 \\
\hline $\mathrm{Pu}-24$ ! & 14.1 & 816 & $8.42 \times 10^{4}$ \\
\hline$P u-24 \%$ & $3.76 \times 10^{5}$ & 305 & 1.16 \\
\hline$A m-2+1$ & 433 & 170 & 584 \\
\hline$A m-242 m$ & 152 & 0.44 & 4.29 \\
\hline$A m-243$ & $3.37 \times 10^{2}$ & 55.3 & 11.01 \\
\hline $\mathrm{C} m-242$ & 0.45 & 0.85 & $2.80 \times 10^{3}$ \\
\hline $\mathrm{Cm}-2+3$ & 28.5 & 6.19 & 9.77 \\
\hline $\mathrm{Cm}-244$ & I8.1 & 14.0 & $1.24 \times 10^{3}$ \\
\hline $\mathrm{Cm}-2+5$ & $8.5 \times 10^{3}$ & 0.57 & 0.10 \\
\hline Cnt-246 & $4.7 \times 10^{3}$ & 0.07 & 0.02 \\
\hline
\end{tabular}

"Calculated from data in DOE/NE-0017/2 11983); half-lives from Friedlander et al. (1981).

are uniformly distributed in the $\mathrm{LO}$, matrix. Figure 7 show's the distribution of $\mathrm{Pu}, \mathrm{Cs}$, Te, and $\mathrm{I}$ in a fuel pellet with a burnup of $28,000 \mathrm{MWd} /$ MTIHM. The fission products are uniform within the pellet while the Pu concentration is enhanced near the peilet surface. This variation in $\mathrm{Pu}$ as a function of position is due to enhanced production of actinides near the pellet surface (Woodley, 1983).

Spent fuel waste testing for NNWSI was focusec! at first on Turkey Point spent fuel, which had an initial enrichment of $2.56 \mathrm{wt} \%, 235 \mathrm{U}$, was hurned to 25,500 to 27,000 \%.1Wd/MTIHM, and has an average fission gas release to the cladding gap of $0.3 \%$. The spent fuel used in current experiments was discharged from Turkey Point on Nov. 25. 1975 (Wilson, 1983) and is representative of modern design fuel pins operated to moderate burnup under reactor conditions that produced limited fission gas migration from the fuel matrix to the cladding gap.

Future spent fuel testing work will use H. B. Robinson PWR fuel pin samples in addition to the Turkey Point samples. Characturistics of the H. B. Robinson spent fuel are sinilar to those of the Turkey- Point sperit fuel (Barner, 1984). The desirability of including samples of spent fuel with higher burnup (>35,000MWd/MTIHM), high fission gas release, and of older pin ciesign (nonpressurized pins) in the testing program will be evaluated in FY 85.

Spent fuel from BWRs may have different radioactive release characteristics than that from PWRs. The potential for differences will be determined by testing samples of moderate hurnup BWR fuel. The specific BWR fue! to be used has not yet been chosent. 

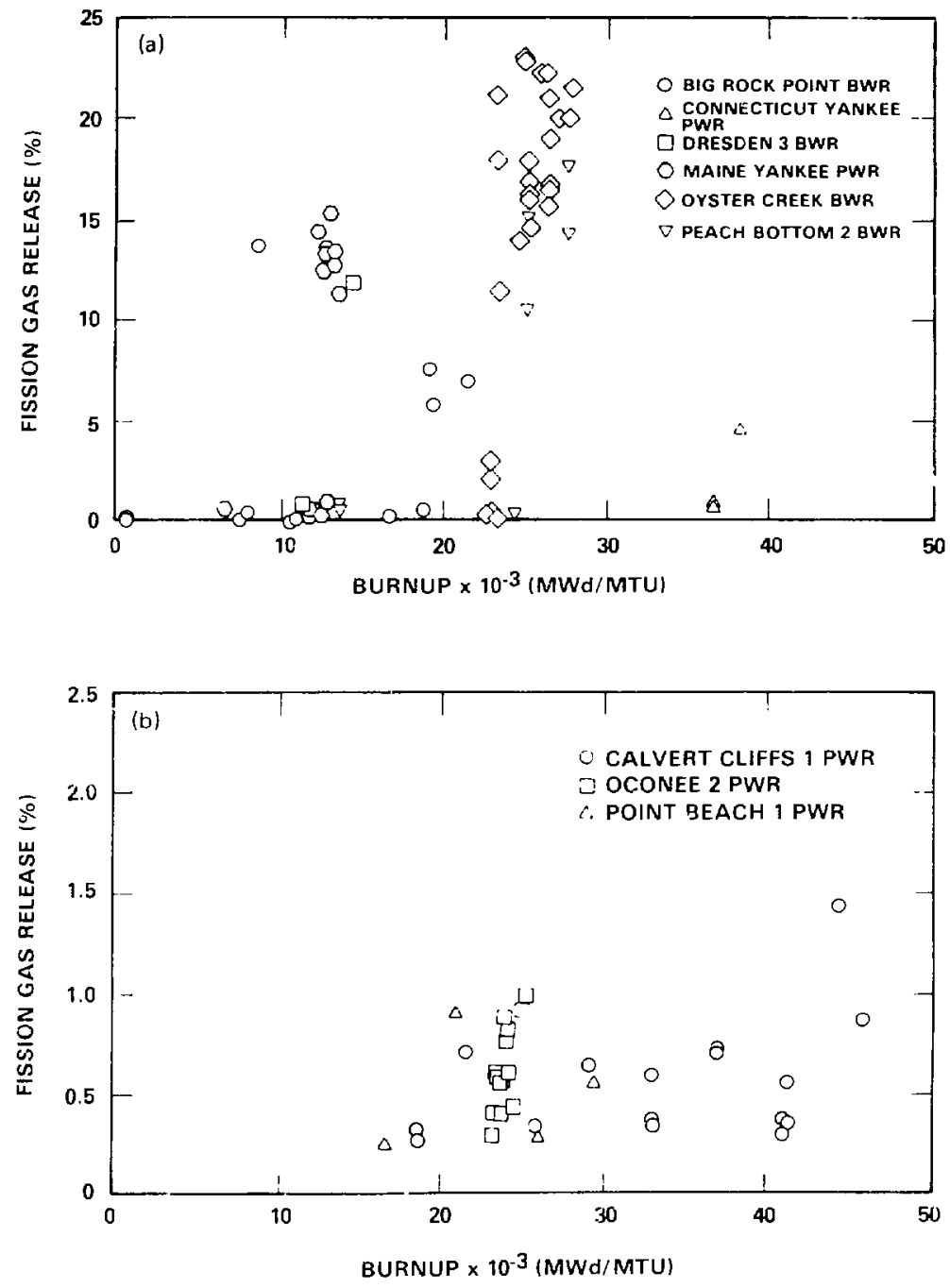

Figure 6. Comparison of fission gas release from (a) unpressurized and (b) pressurized LWR fuel rods (Woodley, 1983). Figure provided by Hanford Engineering Development Laboratory (HEDL), Richland, Wash., Report HEDL-TME 83-28. 


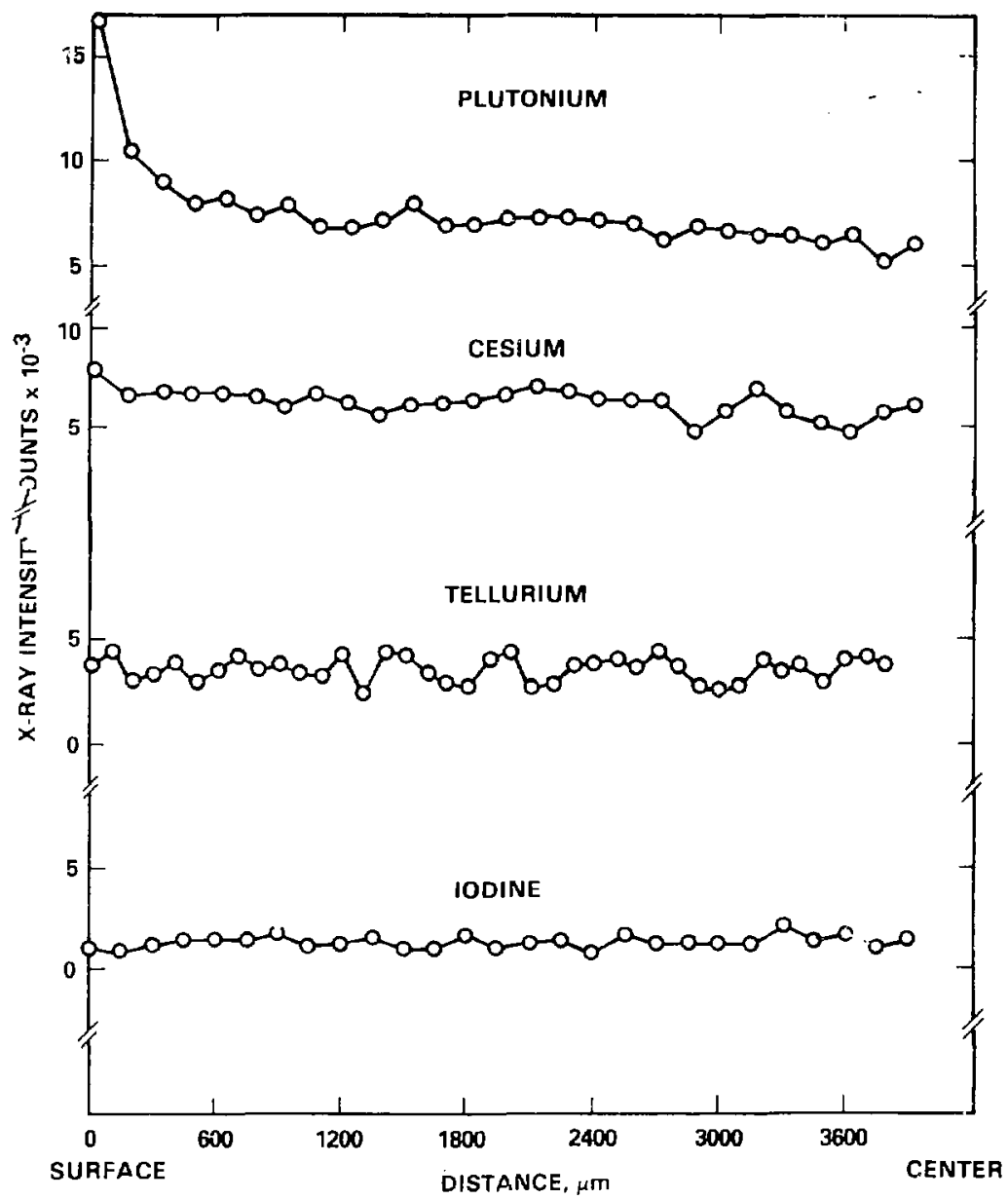

Figure 7. Microprobe measured $x$-ray intensities for Plutonium, Cesium, Tellerium, and Iodine (Woodley, 1983). Figure provided by Hanford Engineering Development Laboratory (HEDL), Richland, Wash., Report HEDL-TME 83-23. 


\section{Defense High-Level Waste}

The Nuclear Waste Policy Act of 9982 contains a requirement that not later than two years atter the date of enactment of the Act (Jan.7, 1983), the President shall evaluate the use of a commer. cial waste repository for disposal of high-level radioactive waste resulting from defense activities. Uniess the President finds (on or before Jan. 7 . 1985) that development of a separate repository for defense wastes is required. DOE is charged by the Ari to arrange to dispose of Defense HighLevel haste (DHIW) in the civilian waste repository.

$\therefore$ Detense Waste Processing Facility (DWPF) in heing constructed at the Savannah River Plant $(S K \Gamma)$ in Aiken, S.C. This facility will solidify the waste presently held in storage lanks at SRS. The waste form will be borosilicate glass cast into 304L 55 canisters (Baxter, 1983). Table 5 outlines the dimensions of the waste canisters. The volume of glass in the canister is approximately $85^{\circ}$ of of the arailable canister volume (Baxter, 1983). The canister will be sealed with an upset resistance weld, the sealing plug will be $5 \mathrm{in}$. in diameter and $0.5 \mathrm{in}$. thick (Baxter, 1983).

Table 5. Dimensions of DWPF waste canisters. ${ }^{a}$

\begin{tabular}{ll}
\hline $\begin{array}{l}\text { Overall length } \\
\text { Outside diameter }\end{array}$ & $9 \mathrm{ft} 10 \mathrm{it.}(300 \mathrm{~cm})$ \\
Wall thickness & $24 \mathrm{in.}(61 \mathrm{~cm})$ \\
Bow & $0.375 \mathrm{in} .(0.95 \mathrm{~cm})$ \\
Inside volume & $0.25 \mathrm{in}(\mathrm{max})(0.64 \mathrm{~cm})$ \\
Weight, empty & $26.1 \mathrm{ft}^{3}(739 \mathrm{~J})$ \\
Weight, full tFril 131) & $1000 \mathrm{lb}(454 \mathrm{~kg})$ \\
Weight, full (Frit 165) & $4260 \mathrm{lb}(1932 \mathrm{~kg})$ \\
\hline
\end{tabular}

"From Baxter (1983).
Several frit compositions have been considered for the DWPF glass. Table 6 presents the chemical composition of four frit materials. Frit 131 is the current reference frit for DWPF design furposes; Frit 165 is a composition that more closely represents the expected frit composition for the final DWPF (I. Plodinec, Savannah River Laboratory (SRI). pers. comm.). Frits 18 and 21 were used carlier in the glass development process.

Waste stored at SRP is in the form of sludge that contains most of the radinnuclides and supernatant materiai that contains radioative cesium. The waste is stored in tanks, which rary in terms of the age of the waste contained and the chemical composition of the waste.

Talles $7-11$ provide a profile of a sludgesupernate representative glass made with Frit 131 and a blend of 5 -yr-old sludge and $15-y-$ old supermate. The anticipated thermal neutron fissionable nuclide concentrations per canister for the reference case waste loading (in units of grams per carister) are U.233 $=0.002, \mathrm{~L}-235=635.7$, Pu-239 $=139.2$, and Pu-241 $=10.8$ (Eaxter, 1983).

All parameters in Talvies $7-11$ are nominal values that were cal-ulated based on 5 -yr-old sludge and 15-yr-old supernate. Much of the waslip at Savannah River Plant is substantially older than that. Preliminary estimates provided to us by Savannah River Laboratory indicate that at the start-up time of the DWPF, the waste canisiers will have a thermal power of only about $75 \mathrm{~W} /$ can and that approximately 3600 cans of this power level will be filled over the first $7 \mathrm{y}$ of DUPF operation (Bibler, SRL. pers. comm.). Subsequent canisters will have a higher thermal power, with the design basis level being reached after approximately 14 yr of operation. The radionuclide content of the early produced glass and

Table 6. Chemical composition of glass frits."

\begin{tabular}{|c|c|c|c|c|c|c|c|c|c|}
\hline \multirow{2}{*}{$\begin{array}{l}\text { Frit } \\
\text { No. }\end{array}$} & \multicolumn{9}{|c|}{ Oxide $(w+7)$} \\
\hline & $\mathrm{SiO}_{2}$ & $\mathrm{Na}_{2} \mathrm{O}$ & $\mathrm{TiO}_{2}$ & $\mathrm{~B}_{2} \mathrm{O}_{3}$ & $\mathrm{Li}_{2} \mathrm{O}$ & $\mathrm{MgO}$ & $\mathrm{ZrO}_{2}$ & $\mathrm{La}_{2} \mathrm{O}_{3}$ & $\mathrm{CaO}$ \\
\hline 18 & 52.5 & 22.5 & 10.0 & 10.0 & .. & - & - & - & 5.01 \\
\hline 21 & 52.5 & 18.5 & 10.0 & 10.0 & 4.0 & - & - & - & 5.0 \\
\hline 131 & 57.9 & 17.7 & $b^{0}$ & 14.7 & 5.7 & $\therefore 0$ & 0.5 & 0.5 & - \\
\hline $165^{\circ}$ & 68.0 & 13.0 & - & 10.0 & 7.0 & 1.0 & 1.0 & - & - \\
\hline
\end{tabular}

"From Baxter (1983).

7 
Table 7. Chemical composition of sludge-supernate glass."

\begin{tabular}{|c|c|c|c|c|}
\hline Component & wt\% & Component & we? & \\
\hline $\mathrm{As}_{2} \mathrm{O}$ & $0.75 E-02$ & MnO & 1.73 & \\
\hline $\mathrm{Al}_{2} \mathrm{O}_{3}$ & 3.35 & $\mathrm{Na}_{2} \mathrm{~B}_{4} \mathrm{O}$ & $0.21 E$ & -03 \\
\hline $\mathrm{B}_{2} \mathrm{O}_{7}$ & 10.59 & $\mathrm{Na}_{2} \mathrm{O}$ & 17.59 & \\
\hline $\mathrm{BaO}$ & $0.39 E-0]$ & $\mathrm{NiO}$ & 0.62 & \\
\hline $\mathrm{Ca}_{3}\left(\mathrm{PO}_{1}\right)_{2}$ & 0.15 & $\mathrm{PbO}$ & $0.41 \mathrm{E}$ & - 01 \\
\hline $\mathrm{CaO}$ & 1.07 & $\mathrm{PuO}_{2}$ & $0.15 E$ & -01 \\
\hline $\mathrm{CuO}$ & $0.16 E-01$ & RhO, & $0.56 E$ & 02 \\
\hline $\mathrm{Cr}_{2} \mathrm{O}_{3}$ & 0.11 & $\mathrm{RuO}_{2}$ & $0.25 E$ & 01 \\
\hline$C s_{2} \mathrm{O}$ & $0.73 E \cdot 01$ & SiO, & 45.09 & \\
\hline CuO & $0.36 \mathrm{E}-01$ & SrO & $0.29 E$ & 01 \\
\hline $\mathrm{Fr}_{2} \mathrm{O}_{3}$ & 6.09 & $\mathrm{ThO}_{2}$ & 0.23 & \\
\hline $\mathrm{reO}$ & 2.70 & $\mathrm{TiO}_{2}$ & 0.72 & \\
\hline Group $A^{\prime \prime}$ & 0.11 & $\mathrm{NO}_{2}$ & 1.20 & \\
\hline Group B' & 0.36 & $\mathrm{Y}_{2} \mathrm{O}_{3}$ & $0.17 \mathrm{E}$ & 01 \\
\hline$h .0$ & $0.19 \mathrm{E} \quad 03$ & Zeolite & 1.47 & \\
\hline $\mathrm{La}_{2} \mathrm{O}_{3}$ & 0.36 & $\mathrm{ZnO}$ & $0.95 \mathrm{E}$ & m \\
\hline $\mathrm{Li}_{2} \mathrm{O}$ & 4.13 & $\mathrm{ZrO}_{2}$ & 0.36 & \\
\hline $\mathrm{s}_{\mathrm{H}} \mathrm{O}$ & 1.59 & & & \\
\hline
\end{tabular}

the surface dune rate from lhose conisters will also be substantially jese than the design basis.

The DHIlif glase that is beirg lested for the NNWSI Project is based on Frit 165. which more likelv reprements the actual product of the DWPF than the reference Frit 1.31 g'ass. The glass that is cur:ently being leented at III.NI. was -upplied to us by SRL in the form of a "mini-pour" ian (SRI. $=171)$. The glan was melted at $1150 \mathrm{C}$ and poured into a 700 -ce $5 S$ beaker. No annealing procedure's were performed (N. Biller, SRL, letter to V. Overstrs Jume o. 1983)

Table 12 lists the nominal composition of the glane as supplient to LI.NL by SRL and the average of the result of electron microprobe analyses performed at I.I.Ni on five samples of the glass. For ach sample, 10 spol analyses ware performed and the data were averaged. The uncertainty estimater given in Table: 12 are based on the standard deviation of the arerage of the live sample averages. The 5RI. data giving the results of a partial analysis by x-ray flucrescence are shown for (omparisoin. 7.eolites are aluminosilicate minerals; thus. the slightly higher $\mathrm{SiO}_{2}$ is the nominal composition in the analysis is easily epplained. Only a portion of the higher $\mathrm{Al}_{2} \mathrm{O}$; can he explained by allewing for the zeolite component. Given the estimated precision of the analy'se's, it seems that the an-fabricated glass contains more $\mathrm{Al}$ than the nominal composition. There also soems to be slightly more $\mathrm{An}$ in the finished product than in the nominal composition. The lower $\mathrm{Na}_{2} \mathrm{O}$ in the electon microprobe analysis may be due to volatalization of $\mathrm{Na}$ during andysis. Data for $\mathrm{MgO}, \mathrm{ZrO}_{2}, \mathrm{Fr}_{2} \mathrm{O}_{3}, \mathrm{CaO}$, and $\mathrm{NiO}$ are in excellent agreement anong the two analyzed values and the nominal composition.

The testing of tully active samples of DHIW glass is in progress at SRI under a cooperative lesting program agreement between LLNL. (repre. senting VNWSI) and SRI. There are currently no. plans to lest fully active DHI.W glass at LLNL. 
Table 8. Radionuclide content of sludge-supernate glass."

\begin{tabular}{|c|c|c|c|c|c|c|c|}
\hline \multirow{2}{*}{$\frac{\text { Isotope }}{{ }^{6} \mathrm{Cr}}$} & \multicolumn{2}{|c|}{$\mathrm{Ci} / \mathrm{lb}$} & \multirow{2}{*}{$\frac{1 \text { sotope }}{12: 5 b}$} & $\mathrm{Cj} / \mathrm{Jb}$ & \multirow{2}{*}{$\frac{\text { Isotope }}{{ }^{\text {imil }} \mathrm{Tb}}$} & \multicolumn{2}{|c|}{$\mathrm{Ci} / \mathrm{Ib}$} \\
\hline & $2.45 \mathrm{E}$ & 20 & & $2.29 \mathrm{E}$ & & $3.09 \mathrm{E}$ & 10 \\
\hline thl $\mathrm{Co}$ & $4.72 E$ & 02 & $12 n 5 b$ & $\therefore 83 \mathrm{E}-07$ & 2015T TI & $2.90 \mathrm{E}$ & 07 \\
\hline${ }^{-4} \mathbf{N i}$ & $5.48 E$ & 04 & $12 m+15 b$ & $4.16 E-05$ & $2: \mathrm{U}$ & $4.03 \mathrm{E}$ & 05 \\
\hline$" \mathrm{Ni}$ & $6.80 \mathrm{E}$ & 02 & $1=5+11 \mathrm{Te}$ & $4.16 \mathrm{E}$ & $\because M U$ & $4.79 E$ & 09 \\
\hline "se & $2.84 t$ & 05 & ${ }^{12} \mathrm{Te}$ & I.R2E & $={ }^{34} \mathrm{U}$ & $1.27 \mathrm{E}$ & 04 \\
\hline${ }^{-} \mathrm{Rh}$ & $1.84 \mathrm{E}$ & 09 & $\mathrm{I}^{-n} \mathrm{Te}$ & $1.86 \mathrm{E}$ & $2 '=U$ & $4.21 \mathrm{E}$ & 07 \\
\hline$" \mathrm{"} \mathrm{S}$ & $2.13 \mathrm{t}$ & 08 & ${ }^{194} \mathrm{Te}$ & $4.621 \cdot 16$ & $=\ln \mathrm{L}$ & $9.18 \mathrm{E}$ & Oto \\
\hline "Sr & $1.21 \mathrm{I}$ & 01 & ${ }^{124 \pi \times} \mathrm{Te}$ & $7.19 \mathrm{E} \cdot 16$ & $2 " \mathrm{~L}$ & $2.35 \mathrm{E}$ & 06 \\
\hline "yll & $-.35 \mathrm{f}$ & 00 & ${ }^{18.4} \mathrm{Cs}$ & $1.05 \mathrm{E} \quad 01$ & ${ }^{21+} N_{p}$ & $+.81 \mathrm{E}$ & 12 \\
\hline${ }^{41}$ & $2.28 \mathrm{~L}$ & $0 \%$ & ${ }^{175} \mathrm{Cs}$ & $2.33[\quad 05$ & $\because N \mathrm{~Np}$ & $\therefore+4 E$ & 06 \\
\hline${ }^{w} Z_{r}$ & $3.11 \mathrm{~F}$ & 04 & $\mathrm{H}^{-} \mathrm{Cs}$ & $1.01 E-01$ & ${ }^{2 / 4} \mathrm{Pu}$ & $2.32 \mathrm{E}$ & 05 \\
\hline${ }^{*} \mathrm{Zr}$ & $2 .-44:$ & Ob & ${ }^{\prime}+\mathrm{Ba}$ & $9.60 \mathrm{E}-00$ & ${ }^{*} \mathrm{Pu}$ & $1.70 \mathrm{E}$ & 15 \\
\hline${ }^{\prime N b}$ & $2.58 \mathrm{~F}$ & 07 & ${ }^{1+1} \mathrm{C}$ & $9.91 \mathrm{E} \quad 15$ & ${ }^{2 * x} \mathrm{Pu}$ & $2.81 E$ & 01 \\
\hline${ }^{4} \mathrm{Nb}$ & 5. HAE & 06 & ${ }^{18} \mathrm{Ce}$ & $2.63 E-09$ & $:{ }^{24} \mathrm{Pu}$ & $2.65 \mathrm{E}$ & 0.3 \\
\hline "N="Nh & $3.45 \mathrm{E}$ & 08 & ${ }^{1+4} \mathrm{Ce}$ & $2.71 E+00$ & $2 M P u$ & $1.68 \mathrm{E}$ & 0.3 \\
\hline${ }^{4+1 C} \mathrm{IC}$ & $5.18 \mathrm{t}$ & 04 & ${ }^{1+4} \mathrm{Pr}$ & $2.71 \mathrm{E} \rightarrow 00$ & $2+1 P=$ & $3.18 \mathrm{E}$ & 01 \\
\hline "Ru $\mathrm{Ru}$ & $5.6 \div:$ & 12 & 114in'Pr & $3.27 E-02$ & $24: P_{4}$ & $2.32 \mathrm{E}$ & $0 b$ \\
\hline$\| r R u$ & $7.5+E$ & 01 & ${ }^{1+4} \mathrm{Nd}$ & $1.33 \mathrm{E} \cdot 13$ & ${ }^{2+1} \mathrm{Am}$ & $2.98 \mathrm{E}$ & 03 \\
\hline I"IsIRh & $5.08 \mathrm{E}$ & 12 & $\mathrm{H}^{2} \mathrm{Pm}$ & $6.65 E+00$ & $24: A m$ & $3.93 \mathrm{E}$ & 06 \\
\hline${ }^{114} \cdot \mathbf{R h}$ & h. $84 \mathrm{E}$ & HT & ${ }^{1+h} \mathrm{Pm}$ & $1.91 E \quad 14$ & IN?m'Am & $3.96 \mathrm{E}$ & 06 \\
\hline$\because " P d$ & $2.58 \mathrm{E}$ & on & 1+km'Pm & $2.77 \mathrm{E} \quad 1.3$ & $2+1 \mathrm{Am}$ & $1.58 \mathrm{E}$ & 06 \\
\hline${ }^{1+\cdots n} \mathrm{An}$ & $3.78 \mathrm{E}$ & v3 & ${ }^{++9} \mathrm{~S} n$ & $5.40 \mathrm{E} \cdot 10$ & ${ }^{*} \mathrm{Cm}$ & $9.65 \mathrm{E}$ & 06 \\
\hline${ }^{113} \mathrm{Cd}$ & $2 .+2 \mathrm{E}$ & 18 & ${ }^{1+k} 5 m$ & $1.5 \% E \quad 15$ & $\because \mathrm{cm}$ & $1.53 E$ & 06 \\
\hline$\because \because m \mathrm{Cd}$ & $5.851:$ & 14 & ${ }^{1+1 "} \mathrm{Sm}$ & $4.82 \mathrm{E} \quad 16$ & ${ }^{2+1} \mathrm{Cm}$ & $4.48 \mathrm{E}$ & 05 \\
\hline 1:1m!5n & B.221 & 06 & ${ }^{111} \mathrm{Sm}$ & $6.72 \mathrm{E} \quad 02$ & $\because{ }^{*} \mathrm{Cm}$ & $1.83 \mathrm{E}$ & 09 \\
\hline$\because \mathrm{Sn}$ & $7.29 \mathrm{E}$ & 05 & Eu & $1.02 \mathrm{~L} \quad 03$ & $2+n \mathrm{Cm}$ & $1.46 \mathrm{E}$ & 10 \\
\hline $13 n \mathrm{nn}$ & $4.14 \mathrm{E}$ & 05 & ${ }^{1=}$ Eu & $1.72 \mathrm{E} \quad 01$ & ${ }^{24} \mathrm{Cm}$ & $1.79 \mathrm{E}$ & 16 \\
\hline $1:+S b$ & 1.471 & 11 & ${ }^{1 F i} \mathrm{Eu}$ & $1.32 \mathrm{E} \cdot 01$ & ${ }^{31 \mathrm{Cm}} \mathrm{Cm}$ & $1.87 E$ & 16 \\
\hline Total activity & \multicolumn{3}{|c|}{$5.42 \mathrm{E}+01 \mathrm{Ci} / \mathrm{lb}$} & & & & \\
\hline \multicolumn{8}{|l|}{ Decay heat } \\
\hline Total primary & \multicolumn{3}{|c|}{$1.05 \mathrm{E} \quad 01 \mathrm{~W} / 1 \mathrm{~b}$} & & & & \\
\hline Total gamimas & \multicolumn{3}{|c|}{$3.93 E \quad 02 \mathrm{~W} / \mathrm{lb}$} & & & & \\
\hline
\end{tabular}

From Baxter (1983). 
Table 9. Physical properties of glass waste forms based on Frit 21 (unless otherwise noted). ${ }^{\circ}$

\begin{tabular}{|c|c|}
\hline Property & Value \\
\hline Thermal conductivily at $100^{\circ} \mathrm{C}$ & $0.95 \mathrm{~W} / \mathrm{m}-{ }^{\circ} \mathrm{K}$ \\
\hline Heal capacity at $100^{\circ} \mathrm{C}$ & $\left.0.22 \mathrm{cal} /(\mathrm{g}) \mathrm{H}^{\circ} \mathrm{C}\right)$ \\
\hline Fractional thermal expansion" & $1.22 \times 10=/ 2 \mathrm{C}$ \\
\hline Young'b modulus' & $62 \mathrm{GPa}$ \\
\hline Tensiles strength & $62 \mathrm{MPa}$ \\
\hline Compressive strenglh & $690 \mathrm{MPa}$ \\
\hline Poisson's ratio" & 0.2 \\
\hline Density at $100^{\circ} \mathrm{C}^{\prime}$ & $2.55 \mathrm{~g} / \mathrm{cc}$ \\
\hline Suftening point & $502 \mathrm{C}$ \\
\hline \multicolumn{2}{|c|}{ 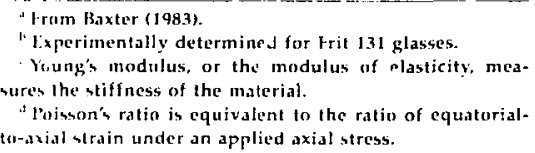 } \\
\hline
\end{tabular}

Table 10. Canister decay heat and activity of sludge-supernate glass."

Ye.tr

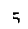

10

17

I!I

25

31

75

$41]$

$+7$

ज11

hill

?11

Bil

4ा1

IIII)

2III)

3)1

H(I)

รIII

b(1)

700

Hoi,

400

1000

\begin{tabular}{|c|c|}
\hline \multicolumn{2}{|c|}{ Sludge-supernate gldss } \\
\hline$\overline{C i} / \overline{c a n}$ & WTesn \\
\hline 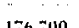 & (1) \\
\hline $1, \theta^{2}, 100$ & \\
\hline 177,4019 & 347 \\
\hline I1s, In! & ithll \\
\hline $11,3,701$ & .3211 \\
\hline $91, \mathrm{~h} 80$ & 255 \\
\hline$B 1,290$ & 255 \\
\hline 72,140 & 238 \\
\hline $6+, 050$ & $21^{2} 4$ \\
\hline 56,840 & 183 \\
\hline $50.5-10$ & $10-1$ \\
\hline $.79,410$ & 132 \\
\hline 31,540 & 107 \\
\hline $2.3,2.30$ & $x=$ \\
\hline 14,7601 & 31 \\
\hline $\mid 5,670$ & 58 \\
\hline 1726 & 12 \\
\hline 314 & 4.5 \\
\hline 114 & 2.6 \\
\hline$=1$ & 1.7 \\
\hline 51 & 1.3 \\
\hline+1 & 1.1 \\
\hline 35 & 0.43 \\
\hline 31 & 0.83 \\
\hline 24 & 0.70 \\
\hline - & $-\cdots$ \\
\hline
\end{tabular}

- I rom Baxter (19k3). 
Table 11. Radiation from sludge-supernate glass canisters.

\begin{tabular}{|c|c|c|c|}
\hline Basis & Case I & Case II & Case II] \\
\hline $\begin{array}{l}\text { Fill height } \\
\text { Glass density }\end{array}$ & $\begin{array}{l}91 \mathrm{in.} \\
2.37 \mathrm{~g} / \mathrm{cm}^{3}\end{array}$ & $\begin{array}{l}91 \mathrm{in} . \\
2.5 \mathrm{~h} / \mathrm{cm}^{\prime}\end{array}$ & $\begin{array}{l}107 \mathrm{in} . \\
2.56 \mathrm{~g} / \mathrm{cm}^{\prime}\end{array}$ \\
\hline Wasle loading & $28 \%$ & $28 r$ & $35 r_{i}$ \\
\hline
\end{tabular}

\begin{tabular}{lccc}
$\begin{array}{l}\text { Distunce } \\
\text { (ft) }\end{array}$ & Case I & Rudiation level (rems/h) \\
\hline Contact & 5500 & 5275 & Case III \\
13 & 4150 & 3895 & 6550 \\
1 & 1785 & 1660 & 4825 \\
3 & 610 & 565 & 2135 \\
4 & 425 & 395 & 73.5 \\
5 & 315 & 290 & 520 \\
10 & 102 & 95 & 340 \\
15 & 49 & 45 & 1.35 \\
20 & 28 & 26 & 65 \\
30 & 13 & 12 & 38 \\
40 & 3.3 & 3 & 17 \\
100 & 1.2 & 1.1 & 4.4 \\
\hline
\end{tabular}

From Baxter (1983).

Table 12. Composition of DHLW glass (simulated waste) used in NNWSI testing.

\begin{tabular}{|c|c|c|c|}
\hline Component & $\begin{array}{c}\text { Nominal } \\
\text { wty }\end{array}$ & $\begin{array}{l}\text { LINL } \\
\text { WI" }\end{array}$ & $\begin{array}{l}\text { SRL" } \\
\text { wt: }\end{array}$ \\
\hline $\mathrm{SiO}_{2}$ & 53.47 & $54.9 \rightarrow 2.1$ & \\
\hline $\mathrm{No}: \mathrm{O}$ & 11.40 & $9.74+0.54$ & \\
\hline $\mathrm{Li}_{2} \mathrm{O}$ & 5.04 & & \\
\hline $\mathrm{B}_{2} \mathrm{O}_{7}$ & 7.20 & & \\
\hline MgO & 0.72 & $0.72+0.04$ & 0.65 \\
\hline $\mathrm{ZrO}_{2}$ & 0.72 & $0.66+0.07$ & 0.58 \\
\hline $\mathrm{Fe}_{2} \mathrm{O}_{1}$ & 10.53 & $10.6+0.7$ & 10.2 \\
\hline $\mathrm{MnO}_{2}$ & 2.35 & $2.72-0.13$ & 2.6 \\
\hline $\mathrm{CaO}$ & 1.37 & $1.51 \cdot 0.32$ & 1.2 \\
\hline $\mathrm{NiO}$ & 1.06 & $0.84+0.24$ & 0.83 \\
\hline $\mathrm{Al}_{2} \mathrm{O}_{3}$ & 3.78 & $5.13 \cdot 0.18$ & \\
\hline Zeolite & 1.68 & & \\
\hline $\mathrm{CeO}_{2}$ & 0.42 & & \\
\hline $\mathrm{K}_{2} \mathrm{O}$ & 0.14 & & \\
\hline $\mathrm{SrO}$ & 0.10 & & \\
\hline $\mathrm{RuO}_{2}$ & 0.036 & & \\
\hline $\mathrm{Cs}_{2} \mathrm{O}$ & 0.0028 & & \\
\hline
\end{tabular}

"Data from Bibler, SRL, pers. comm. 


\section{Commercial High-Level Waste: West Valley}

Wistern New York Nuclear Service Center located near host Valley, N.Y., reprocessed nuckear reactor fuel from both liederal Governnent reactors and commercial power reactors from 1960 to 1972. liquid wastes resulting from those reprocembing activities are currently stored in steel tanks in underground concrete vaults at the lliel Valley site. Congress (Public law 963nci) has directed the Department of Energy' (I)(OF) to corrs ont at the Cenler a demonstration project that will involve solidification of the rastem inte a durable high-lesel nuclear weaste form nuituthe for dinposal. DOE is now the site adminmerare and the thent valley Nuclear Serban Compans: Ins. (WVNSC)-a wholly owned

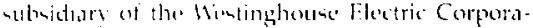

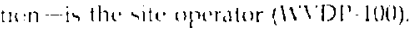

fwe different reper of high-lesed liguid

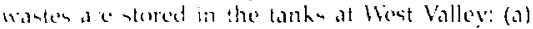
medutraliset l'ure wasten that consist of a layer of 4hadge cowered by a supermalle, hored in a corbon

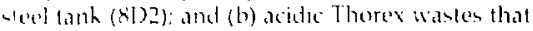
ne stored in a 45 tanh (8D)t). The netutralized Prurex wanten, an will be documented below; are

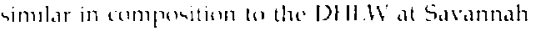
River.

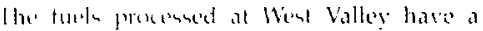
minimum int of rearlor" age in logt of 14 ser and an ax arghe "age" of 17 ir. Many of the ruels represenesed had a low reactor barmup (DOE/EIS-

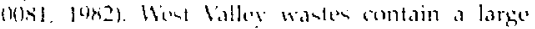
amount of mert mon in the meutralised-ludge, and

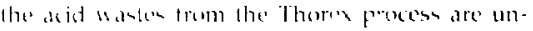

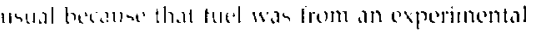
reactor

lis datu, there in vers little dromentation of the atual conterent of radionsuclisten in the storage

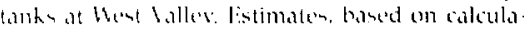

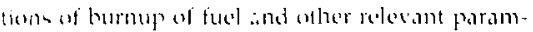

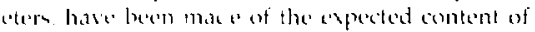
the tank s. A borosilicale glas waste form is being taikened to the expected tank conpositions and

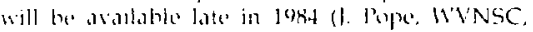
pers (1) (1)

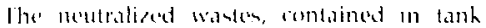

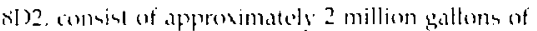
wate generated from the reprosensing of 625 mot ris tom of uranium fuel Approsimately $4 f^{\prime \prime}$ of

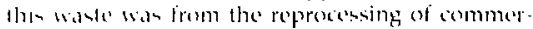

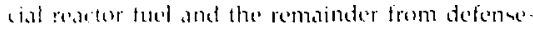

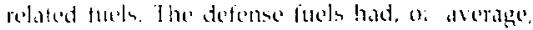
fower burmup: thes, the present radiontise con- tent of the tank is derived primarily from the commercial fucls (DOE/EIS-0081, j982). Table 13 gives the es mated chemical composition of the neutralized wastes contained in the sludge and supernate of tank 8D2. Table 14 gives the estimated radioactivity in the waste as of 1987.

The acidic wastes contained in tank $8 \mathrm{D}+$ were gi erated during the reprocessing of the fuel from an experimental reactor. The fuel contained an original composition of $93.5 \%$ thorium and $6.5 \%$ highly enriched uranium (DOE/ElS-0081, 1982). The wastes were retained as acid solutions to avorid precipitation of thorium. There is some indiation, however, that thorium precipitation has occurred in the acid solutions (DOE/EIS-0081, 1982, p. B-7). Tathe 15 lists the estimated chemical composition of the ardic waste and Tatole 16 lists the estimated radionctlity an of 1987. The estimated fission-prodect inventors in the acid waste is ten times less than that in the noutralised wastere and the transuranic content of the acid wanters is expected to be commensurately less (D) (OF/15-00151, 1982).

The relerence procens tor management of West balley wastes involves the treatment of the supernatant liquid to separate and comeentrate $C_{\text {C }}$ 1.37 and a trace amount of 5r-90. leasing a low. level radioacisice sodium salt te be dispored of separatcis: The sludge from neutralized wastes would be whind with willer to reduee the sodium concentration. The rinste selutions from tike sledge would be treated with the low- level porfions of the :epermate. Mashed gludge and fission products from the supemate wald be combined with the actid wastes and glass frit and would be berided. The blended product would he fed to an electrically hedted, coramic-lined medter. The as.

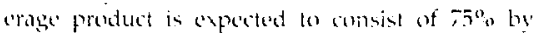
weight ol alhaline (nedutralized) wistes and $25^{\circ}$, ly weight of acid wastes with respect to the radioative components. The final waste form will be approximately 28 " o by weight of wask and 720 ly wight of glase formers (IV'VD-10(1).

Table 17 shows the average expected characteristics of waste ghasses that the West Valley Demunstration Project will produce. The referane deres not state the time for which the curite content per canister is calculated; however, compartion of the values in Tables 14 and 16 divided hy the total canister estimate of 300 suggests that the curie content is approximately the value in 14k3. The curie content per canister is less than 
Table 13. Estimated composition of neutralized Purex wastes (Tank 8D2)."

\begin{tabular}{|c|c|c|c|c|}
\hline \multirow[b]{2}{*}{ Compound } & \multicolumn{2}{|c|}{ In Sludge } & \multicolumn{2}{|c|}{ III Solution } \\
\hline & $10^{3}$ moles & Kilograms & $10^{2}$ moles & Kilograms, \\
\hline$\left(\mathrm{Na}, \mathrm{KI}_{2} \mathrm{SO}_{4}\right.$ & - & - & 630 & 89,800 \\
\hline$(\mathrm{Na}, \mathrm{K}) \mathrm{NO}_{3} / \mathrm{NO}$ & - &. & 12,300 & $1,090,000$ \\
\hline (Nu, K) OII & - & - & 386 & 15.400 \\
\hline$(\mathrm{N}, \mathrm{K}, \mathrm{K}) \mathrm{C})$ & - & - & 8.4 & 500 \\
\hline Fe $(\mathrm{OH})$ & 460 & $+9,500$ & - & - \\
\hline le PO; & 190 & 28,500 & 8.3 & 1.250 \\
\hline $\mathrm{Cr}\left(\mathrm{OH}_{4}\right)^{12}$ & 38 & 3,900 & 21 & 2.100 \\
\hline NilOII," & 18 & 1,700 & 8.3 & $\because 50$ \\
\hline Al $1 \mathrm{OHH}_{3}$ & 11 & 830 & - & - \\
\hline 311 & - & - & $\cdot 18.7$ & . $1,5,0$ \\
\hline 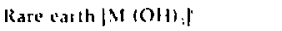 & 9.3 & 1,620 & - & - \\
\hline Fistiun product remainder & & & $2.9^{4}$ & 550 \\
\hline $\mathrm{MA}^{\prime} \mathrm{SO}, \mathrm{I}$ & 5.5 & 1,240 & - & - \\
\hline$\left.\left|M 1^{\prime}\right| O 11\right|_{1} \mid$ & 4.6 & 1,580 & - & - \\
\hline$(1,0,1) \cdot 130,1$ & .07 & 210 & $1.2^{\prime \prime}$ & 220 \\
\hline 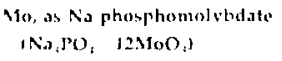 & 7.8 & 980 & 4.2 & 500 \\
\hline Mn, an MnOB, lestimated & 25 & 2,200 & - & - \\
\hline Pu, as PuO: & - & 35 & - & - \\
\hline $\mathrm{L}$ as $\mathrm{Nu}_{2} \mathrm{U}_{9} \mathrm{O}$ & 21 & 6,700 & - & - \\
\hline Actiniden, total as wides & - & 19 & - & - \\
\hline \multirow[t]{2}{*}{ 101915 } & \multirow{2}{*}{\multicolumn{2}{|c|}{$\begin{array}{l}-24,000 \text { liters (ut } \\
\text { assumed dry density } \\
\text { of } 3.5 \mathrm{~g} / \mathrm{mL} \text {. }\end{array}$}} & & $1,203,0000$ \\
\hline & & & & $557 \mathrm{~g} / \mathrm{l}$ \\
\hline
\end{tabular}

"Source: L.h. Department uf tenergy (1979).

"Assuming that the ratio of chromium to nickel is 19:4 the ralio in which it occurs in 304 SSI.

The average atomic weight is $1+3.9$

"IRb. (s) NO, the average molecular weight is 189.52 .

"Technetium as Nalco, lt is very doubtul that this compound of Jc is present: it is most likely lo be gresent as a Ba pertecunctate, coprecipitaled wilh BaSO, Martin \& Miles, "Chemical Prncessing o! Nucelar luels," Academir Presh, $195 \mathrm{~A}, \mathrm{p}$. 7.).

the DWRE estimates for tesign purposes but is similar to the average anticipated output of the DWIPF (sed presding section). The chemical composition of average West Valley wastes is within the anticipated range for the DWPF or can be made so by the addition of inert elements to the glass frit (DOE/EIS-0(181, 1982).

The expected glass composition for West Valley waste will fall within the range expected for DHI.W glosses. A decision on the reference glass composition for Viest Valler will not be made until late 1984 (1. Pope, W'VNSC. peres. conm.). lier these two reasons, NNWSI has decided not to in tiate testing of glass sfecilically relusted to 1 t Vailey wastes unlil a glass composilion is ch:sse by West Valley Nuclear Seivices Company, Inc. after which lesting will be coordinated to derive maximum benefit from previnum experience with DHI.W glasses of similar compositions. 
Table 14. Estimated 1987 radioactivity of neutralized Purex wastes (Tank 8D2)."

\begin{tabular}{|c|c|c|c|c|c|c|c|}
\hline \multirow[b]{2}{*}{ I insion product } & \multicolumn{3}{|c|}{ Radioactivity (curies) } & \multirow[b]{2}{*}{ Actinide } & \multicolumn{3}{|c|}{ Radioactivity (curies) } \\
\hline & Sludge & Supernate & Total & & Sludge & Supernate & Total \\
\hline Fritium (11-3\}) & 0 & $2.4 \times 10^{3}$ & $2.4 \times 10^{4}$ & Uranium-235 & $8.0 \times 10=$ & 0 & $8.0 \times 10=$ \\
\hline Selenium-7y & 0 & $5.0 \times 10^{1}$ & $5.0 \times 10^{1}$ & Uranium-2,38 & $8.2 \times 10^{1}$ & 0 & $8.2 \times 10^{1}$ \\
\hline Strontium-40 & $6.6 \times 10^{\mathrm{h}}$ & $6.7 \times 10^{3}$ & $6.7 \times 10^{n}$ & Neptunium-23 & $2.3 \times 10^{1}$ & $\cdot 1$ & $2.3 \times 10^{1}$ \\
\hline Yttrium-40 & $6.6 \times 10^{\circ}$ & $6.7 \times 10^{4}$ & $6.7 \times 10^{\prime \prime}$ & Neptunium-239 & $2.2 \times 10^{2}$ & $\cdot \mathbf{1}$ & $2.2 \times 10^{2}$ \\
\hline Sirconium-43 & $7.5 \times 10^{\prime}$ & $\cdot 1$ & $2.5 \times 10^{2}$ & Plutonium-2.38 & $1.5 \times 10^{7}$ & 1.5 & $1.5 \times 10^{1}$ \\
\hline Vinbrium-4)?m & $2.4 \times 10^{2}$ & 1 & $2.4 \times 10^{2}$ & Plutonium-239 & $1.8 \times 10^{8}$ & 1.6 & $1.8 \times 10^{8}$ \\
\hline falinetium-44 & 0 & $1.4 \times 10^{7}$ & $1.4 \times 10^{3}$ & Plutunium-240 & $4.7 \times 10^{-2}$ & $\cdot 1$ & $4.7 \times 10^{0}$ \\
\hline Ruthenium- lot & $1.0 \times 10^{2}$ & $1.0 \times 10^{3}$ & $1.1 \times 10^{2}$ & P'utnnium-241 & $3.0 \times 11^{4}$ & $=01 \times 11^{\prime}$ & $=.0 \times 10^{4}$ \\
\hline I2hordium-106 & $1.0 \times 10^{\prime}$ & $1.0 \times 10^{1}$ & $1.1 \times 10^{\circ}$ & Plutonium-242 & $\cdot 1$ & 0 & $-\mathbf{I}$ \\
\hline Pelladium-|ar & $b$ & 1 & 6 & Americium-24l & $2.0 \times 10^{9}$ & $2.0 \times 10^{1}$ & $2.0 \times 10^{4}$ \\
\hline antimonv-125 & $6.0 \times 10^{1}$ & $6.0 \times 10^{\prime}$ & $6.1 \times 10^{i}$ & Americium-242 & $\operatorname{l.d} \times 10^{2}$ & 1 & $1.8 \times 10^{\circ}$ \\
\hline ltollurium-127m & 0 & $6.1 \times 10^{1}$ & $6.1 \times 10^{3}$ & Americium-242m & $1.8 \times 10^{2}$ & 1 & $1.4+10^{2}$ \\
\hline $\operatorname{lin}-176$ & $4.11 \times 10^{1}$ & $\cdot 1$ & $4.0 \times 10^{1}$ & Americium-2.13 & $2.2 \times 10^{2}$ & 1 & $2.2 \times 10^{2}$ \\
\hline sutimous-12um & $4.0 \times 10^{1}$ & $\cdot 1$ & $4.0 \times 10^{1}$ & Curium-2iz & 1 & 11 & $\cdot \mathbf{I}$ \\
\hline Antimuns-12n & $4.0 \times 10^{1}$ & 1 & $1.0 \times 10^{1}$ & Curium-24t & $8.8 \times 10^{\circ}$ & 8.8 & $8.8+10^{\circ}$ \\
\hline londine-124' & 0 & 4.7 & 4.7 & Curium-245 & 1 & 0 & 1 \\
\hline Cenitum-134 & 11 & $2.1 \times 10^{:}$ & $21 \times 111$ & Cuium-24b & 1 & 0 & 1 \\
\hline casium-135 & $" 1$ & $3.5 \times 101$ & $3.5+10^{1}$ & $\operatorname{lot}, 31$ & & & $1.0 \cdot 10$ \\
\hline (amiunt) & 0 & $8.9 \times 10^{\circ}$ & $5.4 \times 10^{\prime \prime}$ & & & & \\
\hline Marium-17\%m & 0 & $8 .+\times 10^{\prime \prime}$ & $8.4 \times 10^{\circ}$ & & & & \\
\hline (eriunt-14t & $1.1 \times 10^{1}$ & 1 & $1.1 \times 10^{t}$ & & & & \\
\hline Prastoudunium-1:44 & $1.1 \times 10^{1}$ & I & $1.1 \times 10^{1}$ & & & & \\
\hline Iramethium-14: & $60 \times 10^{2}$ & h.t), $10^{1}$ & $6.10 \times 11^{1}$ & & & & \\
\hline 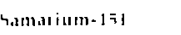 & $2.11 \times 111^{\circ}$ & $2.0 \times 10^{1}$ & $2.11 \times 10^{\circ}$ & & & & \\
\hline 1 uropium-1 iz & 4.1 、110: & 1 & $4.1 \times 10^{\circ}$ & & & & \\
\hline I urspium-19.t & $1.3 \times 111^{\circ}$ & $1.4 \times 10^{3}$ & $1.3 \times 10^{\circ}$ & & & & \\
\hline$|n t, 1|$ & & -. & $3.1: 10^{-}$ & & - & $\ldots$ & \\
\hline
\end{tabular}

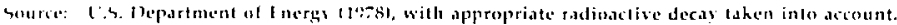

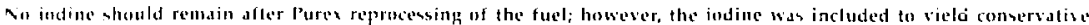
dimase.

lable 15. Lstimated composition of acidic Thorex wastes (Tank 8D -1$\}$ )."

(ompound

I I I I I I. .

$\operatorname{lin}(x)$

vis

II)

II. P(O)

$H: B()$.

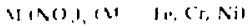

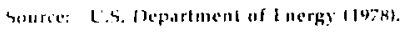

Ipprosimaled 15,500 hg of thorium.

Weight

(netric lons)
Table 16. Lstimated 1987 radioactivity of a idic Thorex wastes (Tank 8DA)."

isuiun producl

Radianclivity (ci)

(ubalt-nu

4ronlium-wh

i t1 ritum-40

$1.5 \times 10^{3}$

$41.5 \times 10$

h.5 $\times 10$

$5+10^{2}$

$6.9 \times 10^{5}$

6. $1 \times 10^{\circ}$

$+.2 \times 10^{\circ}$

Int,a!

$2.6 \times 10^{\text {th }}$

"Source: L'S. Departinent of Inergy (1t)-k), with appropriate radionctive desal laken inlo acrount. 
Table 17. Features of the West Valley Demonstration

Project waste form and canister."

\begin{tabular}{|c|c|}
\hline Feature & $\begin{array}{l}\text { West volley } \\
\text { Reference }\end{array}$ \\
\hline Waste loading & $23 w t^{4}$ \\
\hline Hurosilicate glass densilv & $2.75 \mathrm{~g} / \mathrm{sm} \mathrm{m}^{2}$ \\
\hline Boronilieate glass weight & $1+80 \mathrm{~kg}$ \\
\hline Canuter matorial & 3041 SS \\
\hline Caninter dimensions & $\begin{array}{l}0.6 \mathrm{~m} \text { dian } \\
30 \mathrm{~m} \text { longth } \\
0.95 \mathrm{~cm} \mathrm{wall}\end{array}$ \\
\hline Intal canister weight iwith bormsilicate glass) & $19.30 \mathrm{~kg}$ \\
\hline Hest generation & $3+5 \mathrm{~W}$ \\
\hline Heat generation, after 1000 it & $1 W$ \\
\hline Radionuclide ionten! & $130,000 \mathrm{Ci}$ \\
\hline Radimuarlide contenl, after 1000 yr & $500 \mathrm{Ci}$ \\
\hline Number of canisters & 300 \\
\hline
\end{tabular}

\section{Commercial High-Level Waste: Potential Waste Forms}

There in presently no commercial reprocessing facility lor epent fuel on the United States; thus, there are ro high-level wastes being generated from commerial sources. Should a reprocessing facility be built and begin producing high-level wastes, the winte form for solidification of theme wastes would be tailored to the details of the facility process flow sheet.

In the abence of a dear condidate for commercial high-level waste (CHLWW) forms, the NNivSI Project has chosen as a reference waste form a borosibcate ghass based on the PN1. 76-68 formulation. NiviSl chose PN1. 76-68 because an extensive data base on its physical and chemical propertese ind on the leaching of glass of that general coryosition in deionized water exists. This data base can be used as a starting point tor determining appropriate test conditions that will aid in estimating the long term perform. ance of CHLW glasses in the Yucs Mountain environment.

Mendel el al. (1977) give the reference compusition for PNL 76-68 glass. The glass was hased on lirit 76-101 and waste composition l'W-8a. Table 18 lists the chemical composition of those components and the resulting glass. The waste composition represents the combination of highand internediate-level waste; from a Purex re-

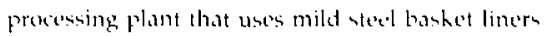
to transfor chopped fuel on the dimolver. The bashe't in discolved along with the opent lusel giving a high iron comlent to the wisto.

Wisste glansen used for pertommance leating are trequently based on a simplification of the ariginal formulation. The ustal cariatione inelude elimination of the noble metale (Ru, $P d, R h)$, which are expensive, a simplification of the suite of rare earth alements to allow une of a relatively inexpensive rare earth mixture in the glans fathriestion, and climination of the artizistem and technetium to simplify handling of the glan. Table 19 outlines the chemical analysin results of glasses laboled MCC-7o-68 plass, which are being resed by the Materials Chatacterization Center (MCC). Battelle Pacific Northwest Laboratory: Richland, Wash. as feed slock for the preparation of two glass testin; mate: ials for VNWSI. The first glass was prepared by doping the base glass with approximately $t^{\circ}, \mathrm{UO}_{2}$. The second glas is being fabricated to include all of the components in the first glass plus $\mathrm{NPO}_{2}(0.4 \%), \mathrm{PuO}_{2}(0.1 \%), \mathrm{Te}_{2} \mathrm{O}$ (0.5\%). $\mathrm{RuO}_{2}(1.0 \%), \mathrm{Rh}_{2} \mathrm{O}_{1}(0.17 \%)$, and $\mathrm{PdO}$ $(0.57 \%)$. NNWSI requested a third glass formulation from MCC with a composition specified to represent a glass sample 300 yr after disposal. 
Table 18. Chemical composition of PNL 76-68 borosilicate glass, Frit 76-101, and waste PW-8a."

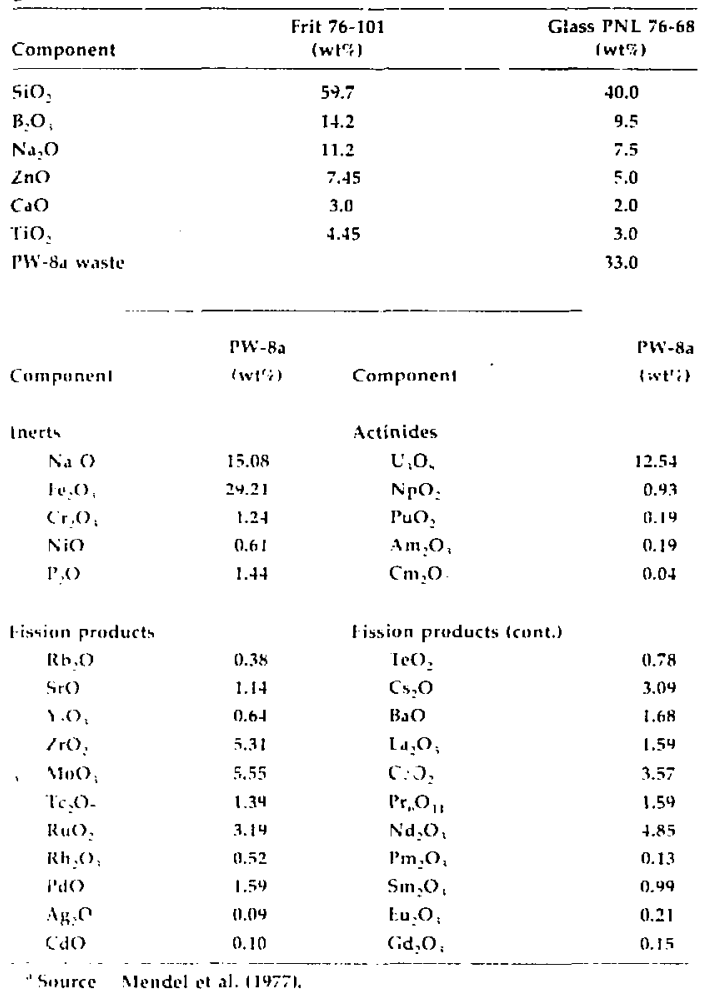

The appeltation "PNI.-76-68" oricinally indicated a specilir melt number (Alendel et al., 1977); it unborident usage has carried a more general moaning and unually indicate a glass that has a omposition similar to tine original PNI. $76-68$ melt run. The composition in 5able 19 differs from the original $76-68$ primarily due to the simplifications mentioned above and the addition of $\mathrm{Al}_{2} \mathrm{O}_{3}$ fo the glass formulation. 
Table 19. Composition of MCC-76-68 glass."

\begin{tabular}{|c|c|c|c|c|c|c|}
\hline \multirow[b]{3}{*}{ Oxide } & \multicolumn{6}{|c|}{ Compositions $\left(w^{\prime} t^{\prime}\right)^{\prime \prime}$} \\
\hline & \multicolumn{2}{|c|}{ Lot 1} & \multicolumn{2}{|c|}{ Lot 2} & \multicolumn{2}{|c|}{ Lot 3} \\
\hline & $w 1 \%$ & $\begin{array}{l}\text { Standard } \\
\text { deviation' }\end{array}$ & wit; & $\begin{array}{l}\text { Slandard } \\
\text { deviation' }\end{array}$ & wet: & $\begin{array}{l}\text { Standard } \\
\text { deviation }\end{array}$ \\
\hline $\mathrm{Al}_{2} \mathrm{O}$ & 0.84 & 0.43 & 0.6 .3 & 0.03 & 0,54 & 0.02 \\
\hline $\mathrm{B}_{2} \mathrm{O}_{4}$ & 8.65 & 0.06 & 8.94 & 0.15 & 9.06 & 0.01 \\
\hline $\mathrm{BaC}$ & 0.62 & 0.01 & 0.54 & 0.02 & $0 . \overline{5}, 5$ & n.00 \\
\hline $\mathrm{CaO}$ & 2.29 & 0.04 & 2.22 & 0.11 & 2.37 & 0.04 \\
\hline $\mathrm{CdO}$ & 0.05 & 0.01 & i.sis & 0.01 & 0.05 & 0.01 \\
\hline $\mathrm{CeO}:$ & 0.02 & - & 0.82 & 0.11 & 0.92 & 0.01 \\
\hline $\mathrm{Cr}_{2}\left(\mathrm{l}_{3}\right.$ & 0.50 & 0.112 & $0 . ;=$ & 0.01 & $0.4 \%$ & 0.01 \\
\hline $\mathrm{Cs}_{2} \mathrm{O}$ & 1.21 & 0.08 & 1.14 & 0.01 & 1.11 & 0.06 \\
\hline $\mathrm{DY}_{2} \mathrm{O}$ & 0.01 & 0.00 & 0.01 & 0.60 & 0.01 & 0.00 \\
\hline $\mathrm{ILu}_{2} \mathrm{O}_{3}$ & 0.01 & 0.00 & 0.01 & $n .00$ & $n .01$ & 0.00 \\
\hline $\mathrm{Fe}_{2} \mathrm{O}$ & 9.08 & 0.12 & 9.52 & 0.17 & 9.51. & 013 \\
\hline $\mathrm{Gd}_{2} \mathrm{O}:$ & 0.13 & $0 . n t$ & 0.02 & 0.00 & 0.02 & $0.0 t$ \\
\hline $\mathrm{K}, \mathrm{O}$ & 0.09 & 0.0 .3 & 0.27 & 0.06 & $0.0 \mathrm{~b}$ & - \\
\hline $\mathrm{La}_{2} \mathrm{O}_{1}$ & 4.54 & 0.06 & 4.33 & 0.24 & $4.1 \mathrm{~h}$ & 0.05 \\
\hline $\mathrm{MgO}$ & 0.18 & 0.01 & 0.14 & 0.01 & O.in & 0.01 \\
\hline $\mathrm{MnO}$ & $0.0 \mathrm{t}$ & 000 & 0.06 & $10.0 \mathrm{I}$ & $0.0 \mathrm{~h}$ & 0.01 \\
\hline $\mathrm{HoO}$ & 2.17 & $0.0:$ & 1.96 & 0.05 & 1.97 & 0.03 \\
\hline $\mathrm{Na}_{2} \mathrm{O}$ & {$[1.60$} & 0.95 & 11.30 & 0.20 & 12.7 & 1.21 \\
\hline $\mathrm{Nd}_{3} \mathrm{O}_{3}$ & 1.65 & 0.01 & 1.47 & $0.0 \mathrm{H}$ & 1.41 & 0.02 \\
\hline $\mathrm{SiO}$ & 0.23 & 0.03 & 0.22 & 0.02 & 0.27 & 0.01 \\
\hline $\mathrm{P}_{2} \mathrm{O}$ & ic in & 0.08 & 0.66 & 0.11 & 0.80 & 0.16 \\
\hline $\mathrm{SiO}_{2}$ & 10.33 & 0.81 & 40.7 .3 & 0.32 & +2.00 & $0.2 n$ \\
\hline $\mathrm{SrO}_{2}$ & 0.19 & 0.01 & 0.42 & 0.01 & 0.42 & 0.01 \\
\hline $\mathrm{TiO}_{3}$ & 286 & $0.0 \dot{+}$ & 3.04 & 0.03 & 3.08 & 0.05 \\
\hline $\operatorname{ZnO}$ & 1.55 & 0.08 & 1.76 & 0.05 & 5.10 & 0.46 \\
\hline $\mathrm{ZrO}$ & 2.3 .3 & 0.04 & 1.79 & a.e: & 1.84 & 0.04 \\
\hline TOTAL & 95.50 & & 95.57 & & 48.76 & \\
\hline
\end{tabular}

"Source: Mellinger and Danicl 119831.

1. Based un analysis of three bars for each lot.

' SIandard deviation of a single analysis.

\section{Packing Material}

Preliminary extimates of rellease rates from waste forms indicaled that for porosilicate glass waste forms in the Topopah Spring, the release of radionuclides for unsaturated conditions would be less than 1 part in 100,000/yr for hll relevant species. For spent fuel, the situation is less clear and may depend on the condition of the Zircaloy cladding. To increase our options with respect to the control of release of radionuclides from the engineered barrier system, we have been investigating the potential use of a packing material as part of the waste package for spent fuel.
Chemical interactions become increasingly compilex as the number of components in the sy"tem is increased. To minimize the potential for deleterious internctions anong the sustem components and at the same time gain the positive features of packing material, we have chosen one based on crushed tuff. The reference packing material is Topopah Spring tuff crushed to pass 100mesh screen and compressed isostatically at $20,000 \mathrm{psi}$. Alternative packing materials involve the reference material plus additive to improve the quality of the final product. Additives under 
investigation include iron-smectite clays and silica gel.

The primary purpose of packing material in the spent fuel waste package would be to provide a region around the spent fuel where the water flow mechanism is known to be porous media flow: Danici it al. (1982) used crushed devitrified Topopah Spring tuif with similar mineralogy to that capected for the repository horizon in batch sorplion studies. They found sorption ratios (in $\mathrm{ml} / \mathrm{gm}$ ) of 54 for Sr. 365 for Cs, 2500 for Am, 1330 for $\mathrm{Tu}_{\mathrm{u}} 1.2$ for $T c$, and 33 for $\mathrm{Np}$. Consequently, the packing material can be expected to provide some retardation of radionuclide release due to sorption.

A iabricated packing material will probably have a thermal conducti ty that is substantially less than that of the rock from which the material was made and of the repository host rock. Consequently, the packing material would cause waste form lemperatures to he higher than for waste packagen that did lot inducie packing materia!. If the contrast in thermal conductivity between the host rock and the packing material is loo great, the thermal leading of the waste packages might have to be decreased, which would result in an increaned total number of waste packagess and commensurately increased cents.

Becaluse the themal conductivity of the packing malcrial may be a limiting lactor in the waste pachage design, we have direded the initial of forte in parking material deselopment loward detemining the babrication techniques that will provide reliable high-denaty products. This will help of provide high themal conduclivity in the fininged prodtec. Alechanical properties of the paching material a.e also important hecause of the hathdling operalion insolved in assembling the wianc package. Initial fabricalion trials used two sises of crushed malcrial to determine whether gram sise alfecled the density of the comprensed samples and their mechanical stubility:

Crushed loperpah Spring tuff was prepared In Iwo size ranges: low than sol mesh and less than 100 mesh. An altempt te compact material crushed to less than 18 mesh was unsuccesstul because the sample was too fragile to handle follow'ing compation. Samples are compacted using iso- latir pressure. $A$ thin Toflom liner is used between the outer Tygon jacket and the crushed ruch to present the sample from stisking to the jasket. If the feflon liner had not been used, the finished sample would have pulled apart as "poker chips" when the pressure was released. Table 20 gives the density of the finished samples as a function of confining pressure. For confining pressures of $15,000 \mathrm{psi}$ or mcre, the density increases only slightly as the compaction pressure is increased. This is a favorable characteristic from the point of view of process control during fabrication, since rather large variations in pressure would have only a small effect on sample quality. Samples prepared from the liner-grained material had better mechanical stability than those prepared from the coarser material.

To determine the thermal conductivity of the packing material, a large sample was prepared using approximately $1 \mathrm{~kg}$ of crushed tuff. The sample was isostatically pressed at $25,000 \mathrm{psi}$, removed from the pressing jacket, and placed in an aluminum canister. A central hole was drilled in the sample and a line heater assembly $n$ as placed in the hole. Thermocouples were placed on the sample surface and in the heater assembly. Thermal conductivi:, was measured at room temperature (approx, $20^{\circ} \mathrm{C}$ ) $60^{\circ}, 100^{\circ}, 130^{\circ}, 165^{\circ}$, and $200^{\circ} \mathrm{C}$. Data points were taken on the heating $\mathrm{cy}$ cle, with two measurements at each temperature; Fig. 8 plots the results. Duplicate measurements at $20^{\circ} \mathrm{C}$ and $100^{\circ} \mathrm{C}$ gave the same value and are shown as a single point in each case. The agreement between results at the same temperature is very good, and the thermal conductivity seems to be essentially independent of lemperature.

The measured conductivity for the fabricated somple is approximately one-thire of that for the rock that was used as the starting material. In an

Table 20. Test results of the Cabrication of the packing material.

\begin{tabular}{ccc}
\hline $\begin{array}{c}\text { Mesh size } \\
\text { of powder }\end{array}$ & $\begin{array}{c}\text { Compacting } \\
\text { pressure (Kpsi.) }\end{array}$ & $\begin{array}{c}\text { Density } \\
\mathrm{g} / \mathrm{cm}^{2}\end{array}$ \\
\hline 60 & 15 & $1.73+0.06$ \\
60 & 25 & $1.75 * 0.06$ \\
100 & 10 & $1.55 \pm 0.03$ \\
100 & 15 & $1.64 \pm 0.03$ \\
100 & 20 & $1.65 \pm 0.03$ \\
100 & 25 & $1.71 \pm 0.03$ \\
100 & $30 \mathrm{~A}$ & $1.65: 0.04$ \\
100 & $30 \mathrm{~B}$ & $1.69 \pm 0.04$ \\
100 & 35 & $1.72+0.03$ \\
\hline
\end{tabular}




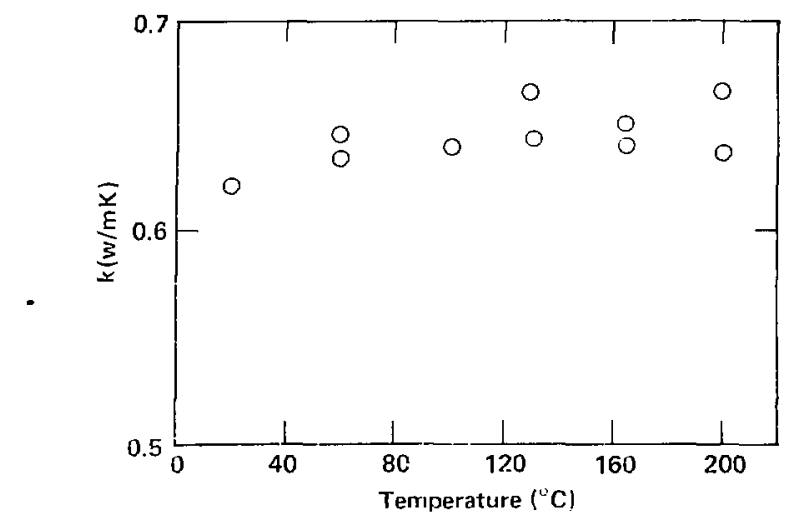

Figure 8. Thermal conductivity vs temperature of compressed Topopah Spring crushed tuff packing material.

attempt to improve the sample density and thermal anduclivity, a sample was prepared using a mixture of $45 \%$ crushed tuff plus $5 \%$ bentonite clay. The finished sample was considerably less friable than the samples made from crushed tuff alone, but the density and thermal conductivity of the mixture were the same as that for samples made with crushed tuff alone. Future work on packing materiai development will focus on the use of other additives to atlempt to improve the density, mechanical stability, and thermal conductivity of the fabricated materials.

\section{Acknowledgments}

Packing malerial fabrication, density determinations, and thermal conductivity measurements were done by K. Keller. His careful work and prompt response are greatly appreciated. The manuscript was improved by' resew comments from R. Van Konynenburg and L. Bailou. 


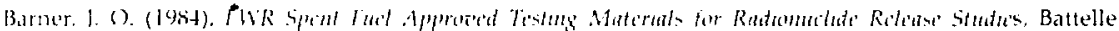
Partic Nirlhwest laboratory, Richland, WA, Report PNL-4686.

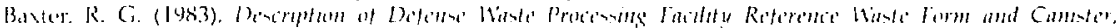
I. I. dulon: de Nemours \& Co.. Sacannah River lahuratory, Aiken, SC, Report DP-1606, Rev. 1.

1).nied, H. R., R D. Aguilar, B. P. Bayhurs, D. I. Bish, M. R. Cisneros, and B. N. Crowe (1982), stmmary

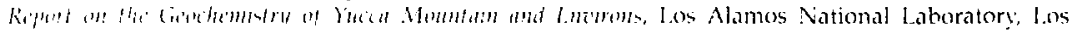
Alamom, NiN, Report 1.A.9328-isS.

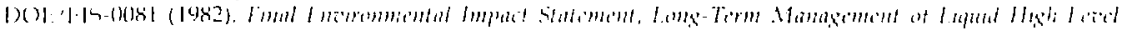

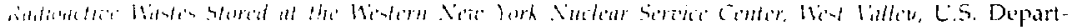
ment al teners!:

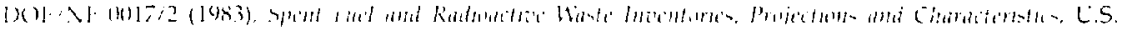
Department of linergy.

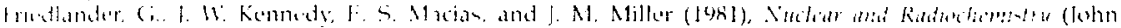

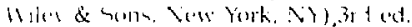

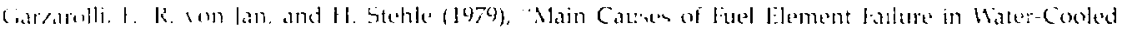

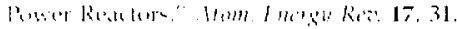

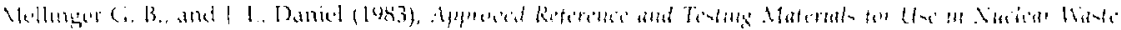

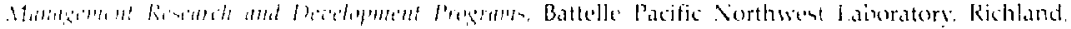

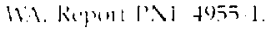

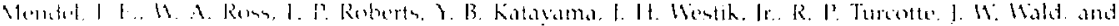

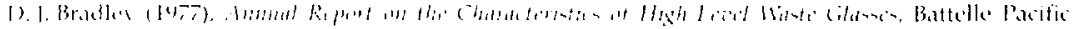

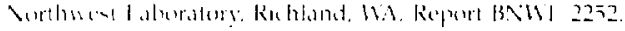

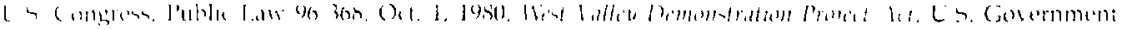

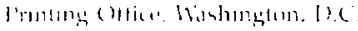

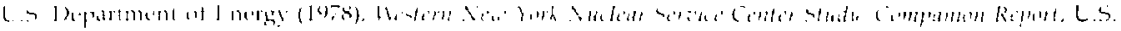

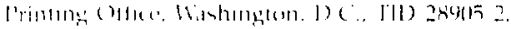

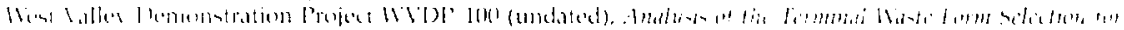

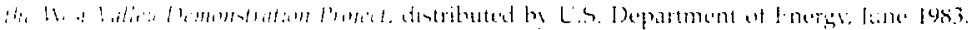

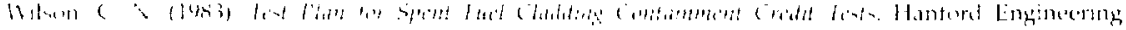

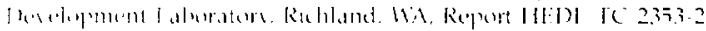

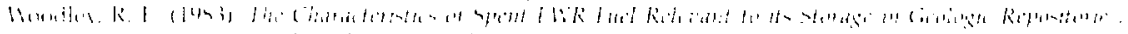

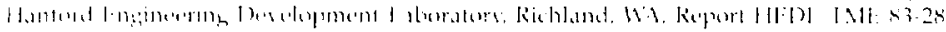

